\title{
One-Pot Aldol Cascade for the Preparation of Isospiropyrans, Flavylium Salts and bis-Spiropyrans
}

Taylor A. Neal, ${ }^{[\mathrm{a}]}$ Allyson B. Eippert, ${ }^{[\mathrm{a}]}$ Austin Chivington, ${ }^{[\mathrm{b}]}$ Andrew Jamison, ${ }^{[\mathrm{b}]}$ Chukwunalu Chukwuma, ${ }^{[\mathrm{b}]}$ Curtis E. Moore, ${ }^{[\mathrm{a}]}$ Jennifer F. Neal, ${ }^{[\mathrm{a}]}$ Heather C. Allen, ${ }^{[\mathrm{a}]}$ Laura M. Wysocki, ${ }^{[\mathrm{b}]}$ Noel M. Paul, ${ }^{[\mathrm{a}]}$ Jovica D. Badjić* $*$ a]

${ }^{[a]}$ Department of Chemistry and Biochemistry, The Ohio State University, 100 West 18th Avenue, Columbus Ohio 43210 (USA) E-mail: badjic.1@,osu.edu

${ }^{[\mathrm{b}]}$ Department of Chemistry, Wabash College, $301 \mathrm{~W}$. Wabash Avenue, Crawfordsville, IN 47933. 


\section{Table of Contents}

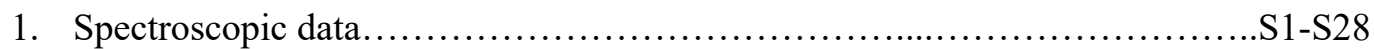

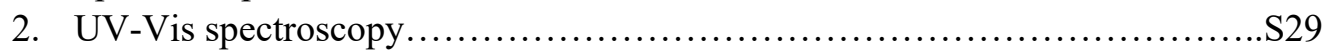

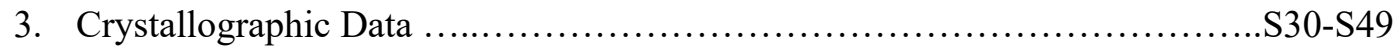




\section{Spectroscopic Data}

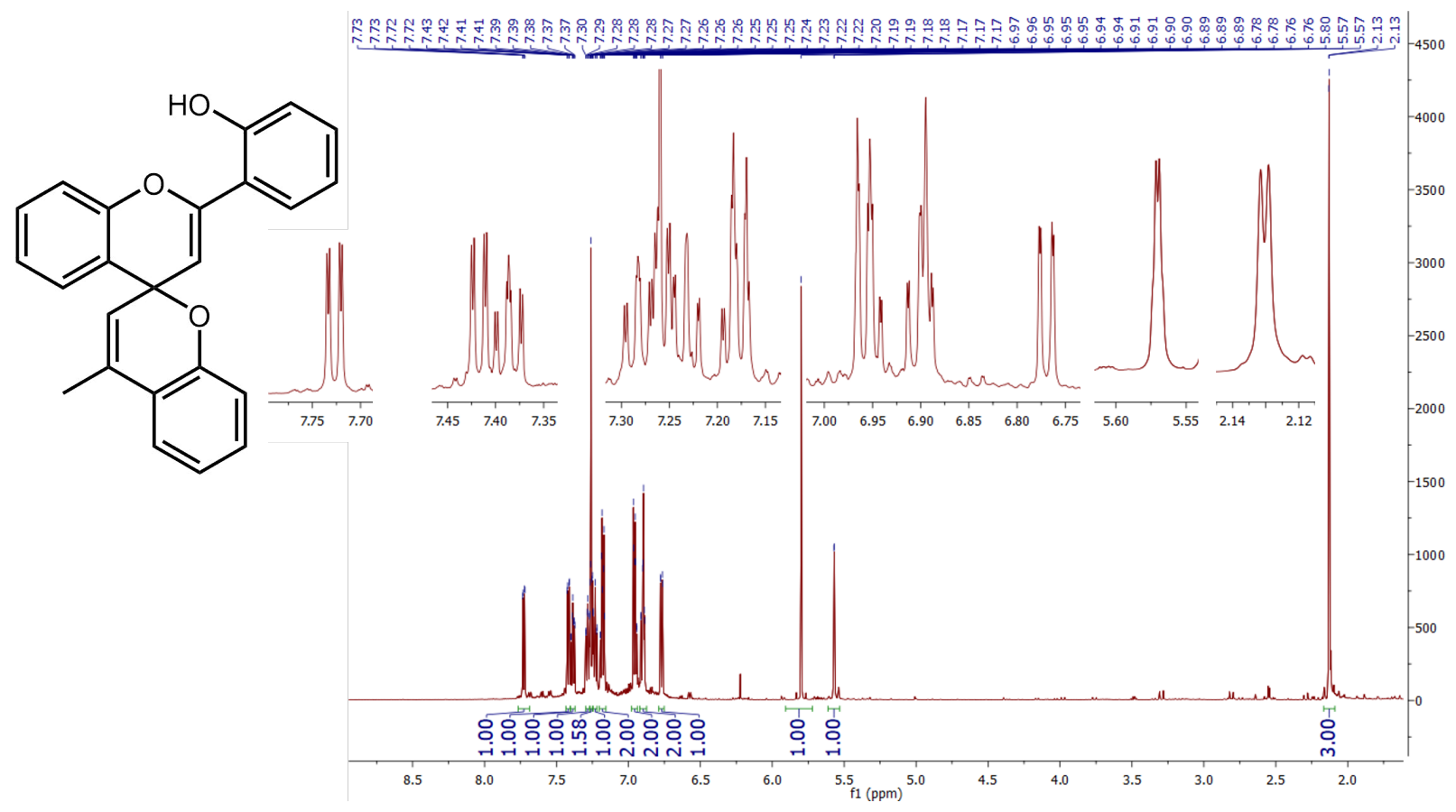

Figure S1. ${ }^{1} \mathrm{H}$ NMR spectrum $(600 \mathrm{MHz}, 298 \mathrm{~K})$ of isospiropyran 11 in $\mathrm{CDCl}_{3}$.

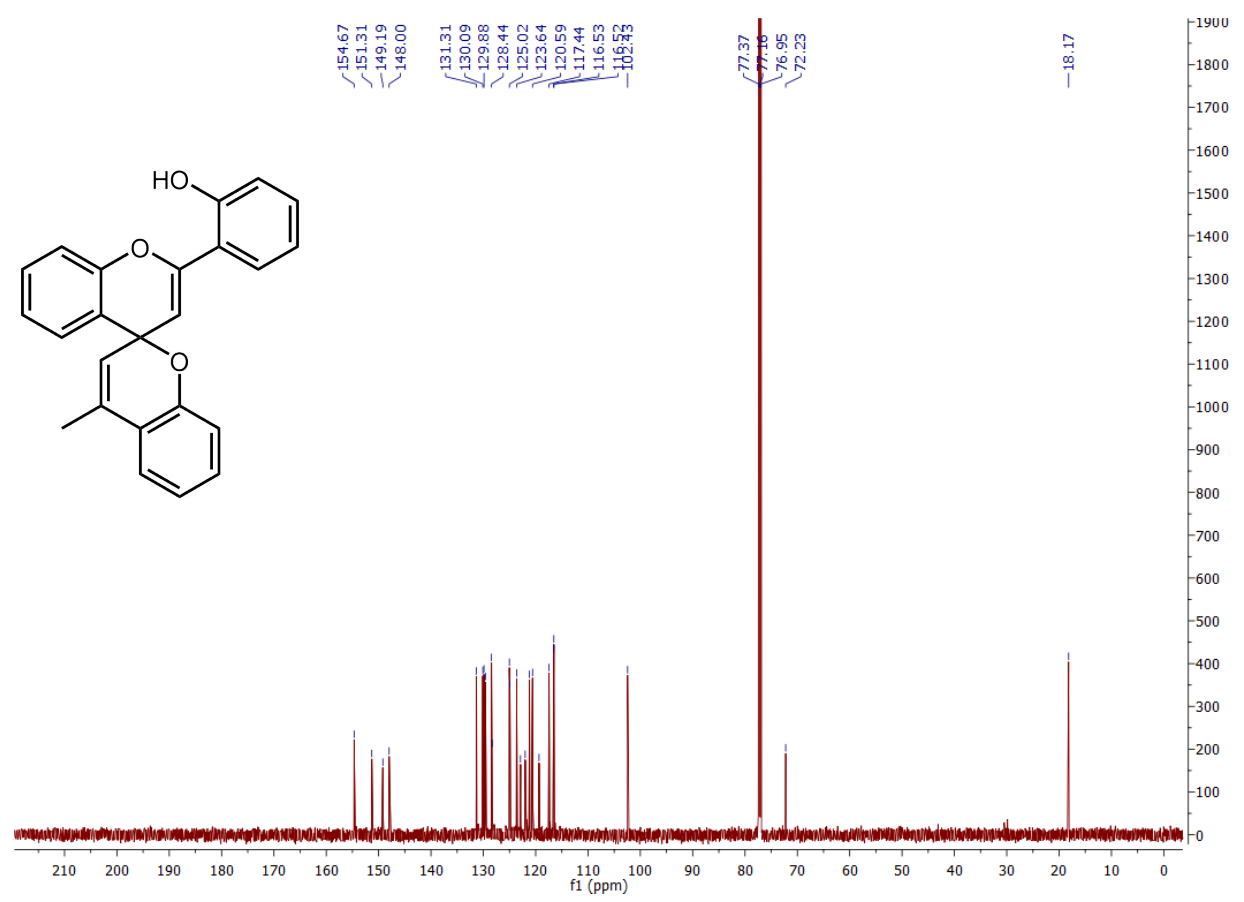

Figure S2. ${ }^{13} \mathrm{C}$ NMR spectrum $(150 \mathrm{MHz}, 298 \mathrm{~K})$ of isospiropyran 11 in $\mathrm{CDCl}_{3}$. 

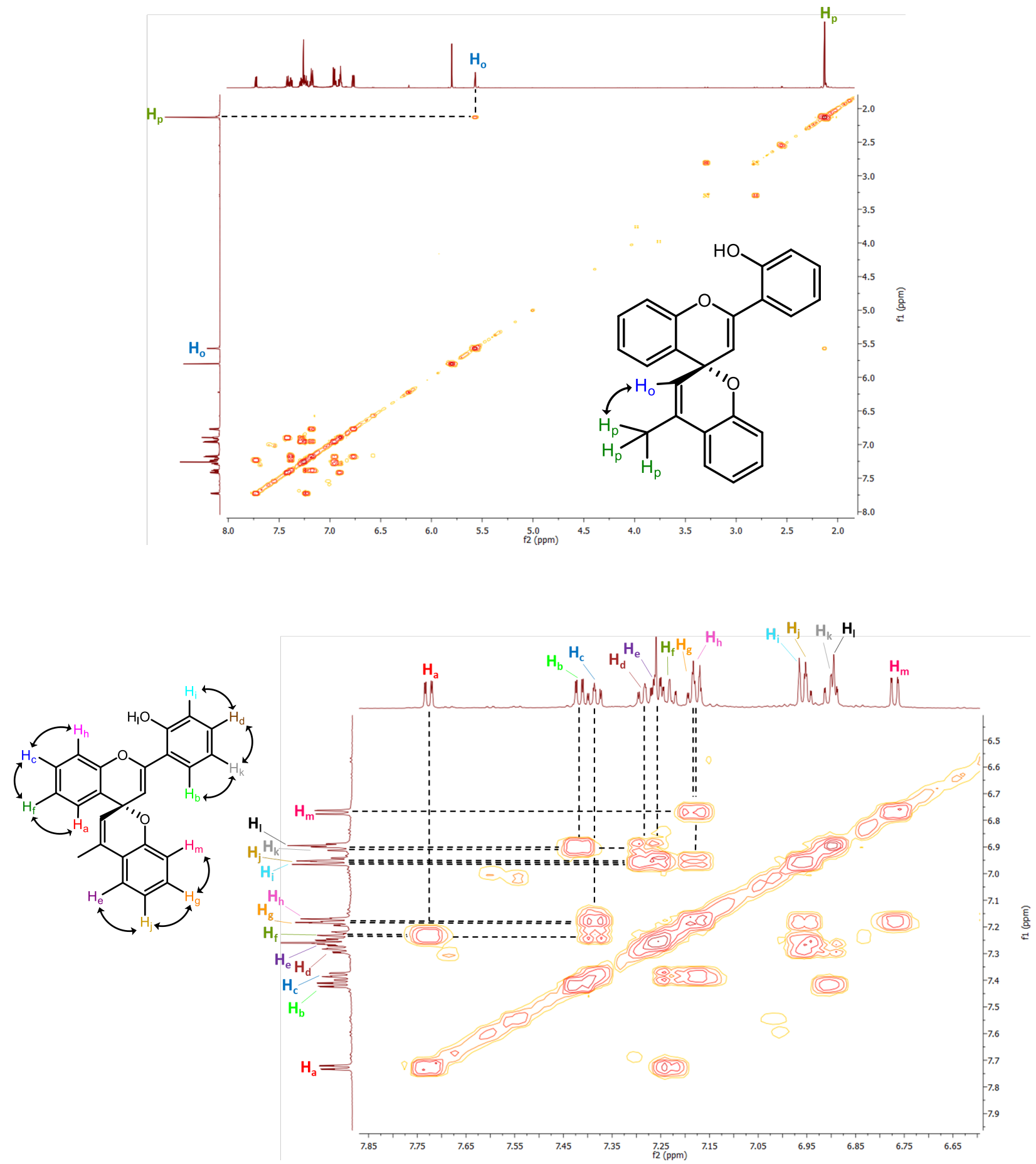

Figure S3. Two different regions of ${ }^{1} \mathrm{H}-{ }^{1} \mathrm{H}$ COSY NMR (600 MHz, $\left.298 \mathrm{~K}\right)$ spectrum of isospiropyran 11 in $\mathrm{CDCl}_{3}$. 

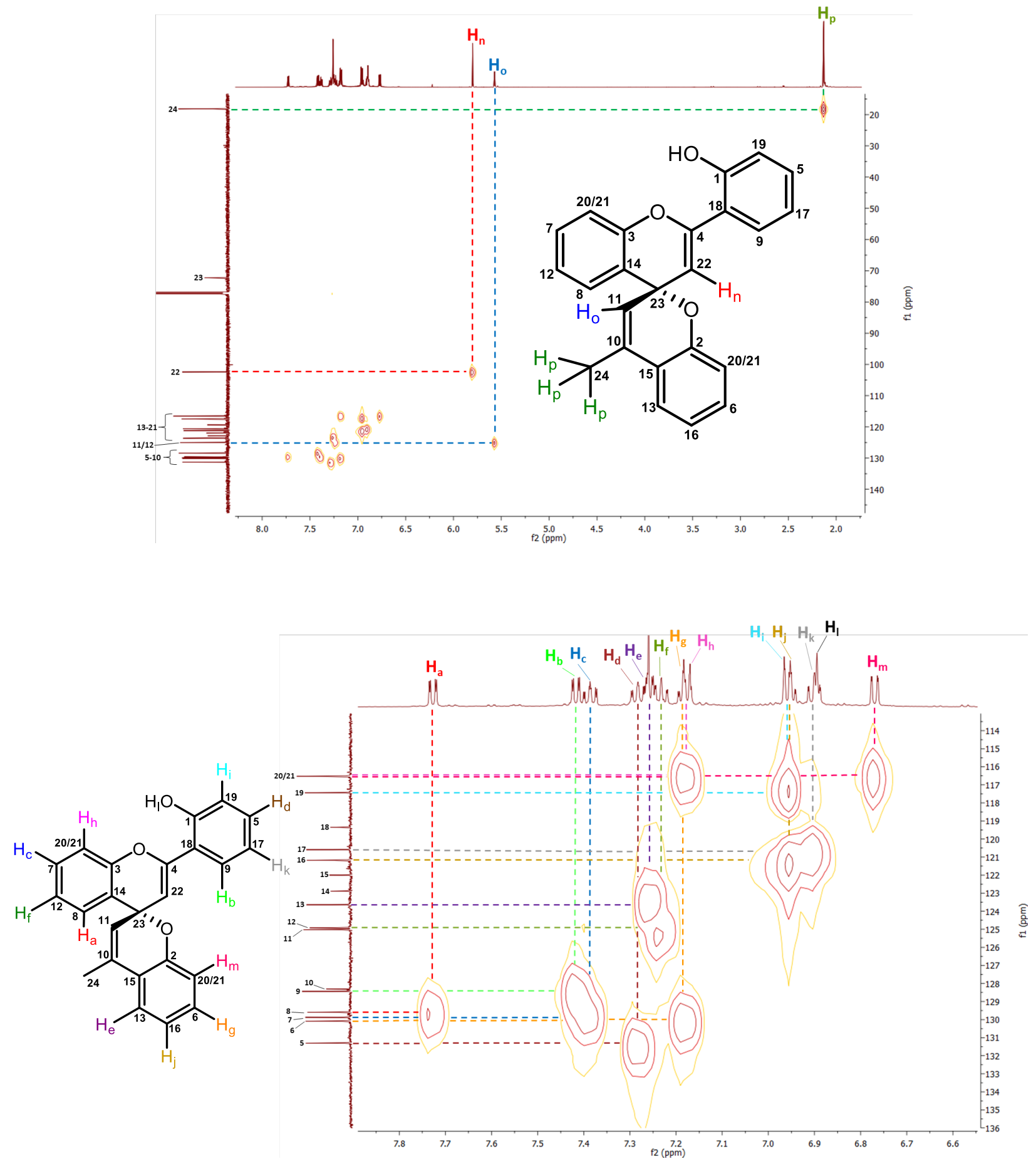

Figure S4. Two different regions of ${ }^{1} \mathrm{H}^{-13} \mathrm{C}$ HSQC NMR (600 MHz, $298 \mathrm{~K}$ ) spectrum of isospiropyran 11 in $\mathrm{CDCl}_{3}$. 

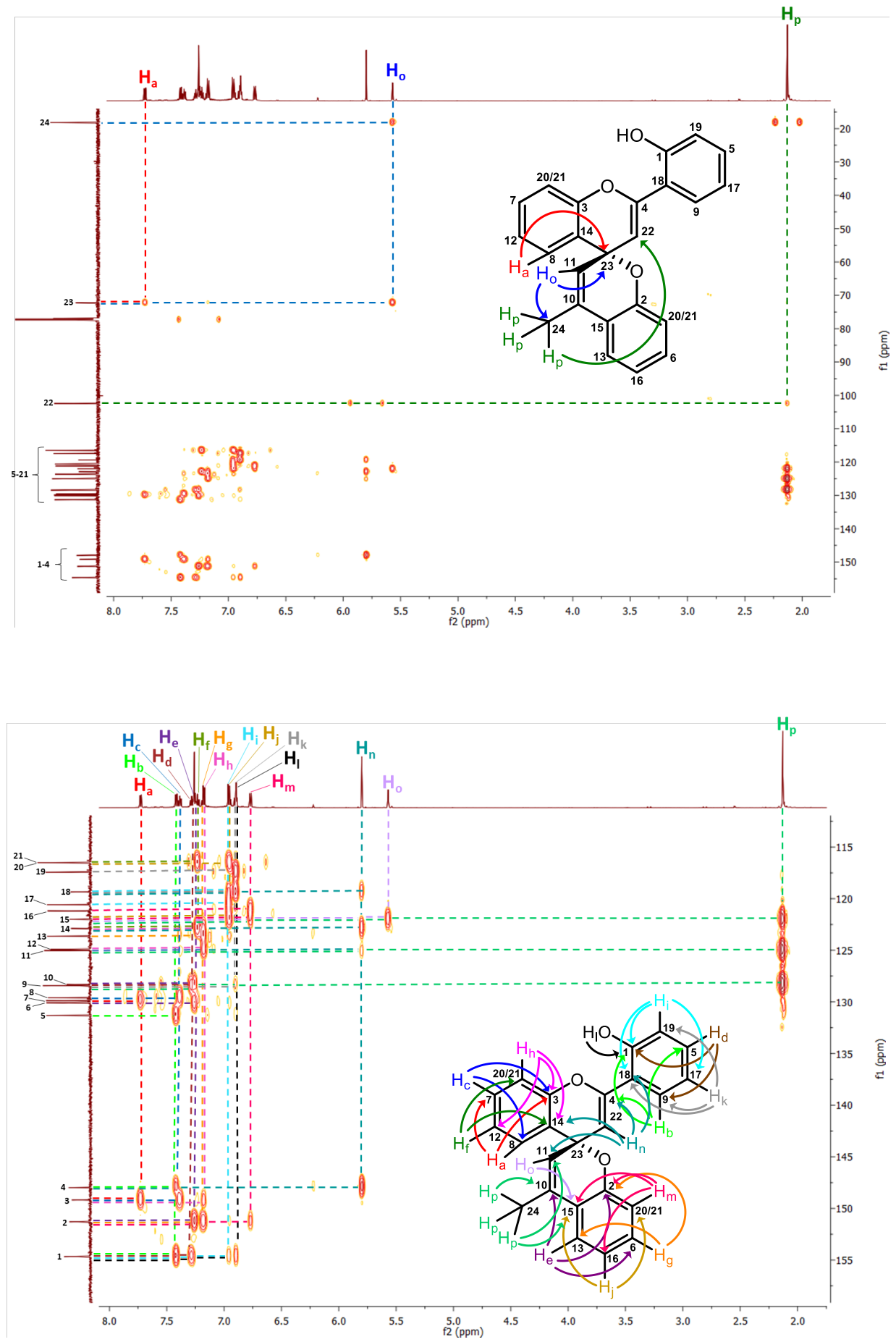

Figure S5. Two different regions of ${ }^{1} \mathrm{H}-{ }^{13} \mathrm{C}$ HMBC NMR (600 MHz, $298 \mathrm{~K}$ ) spectrum of isospiropyran 11 in $\mathrm{CDCl}_{3}$. 


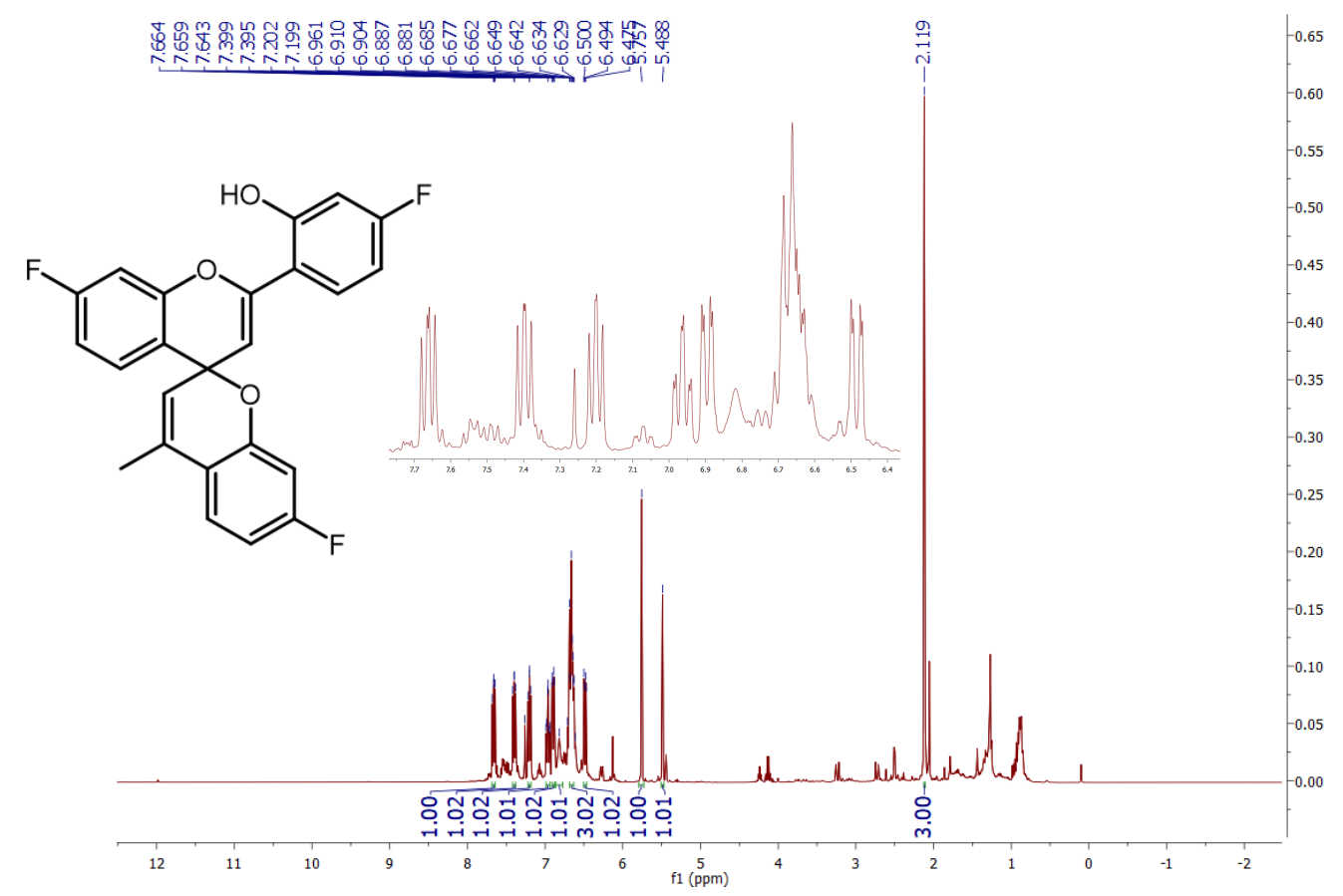

Figure S6. ${ }^{1} \mathrm{H}$ NMR spectrum $(400 \mathrm{MHz}, 298 \mathrm{~K})$ of isospiropyran 12 in $\mathrm{CDCl}_{3}$.

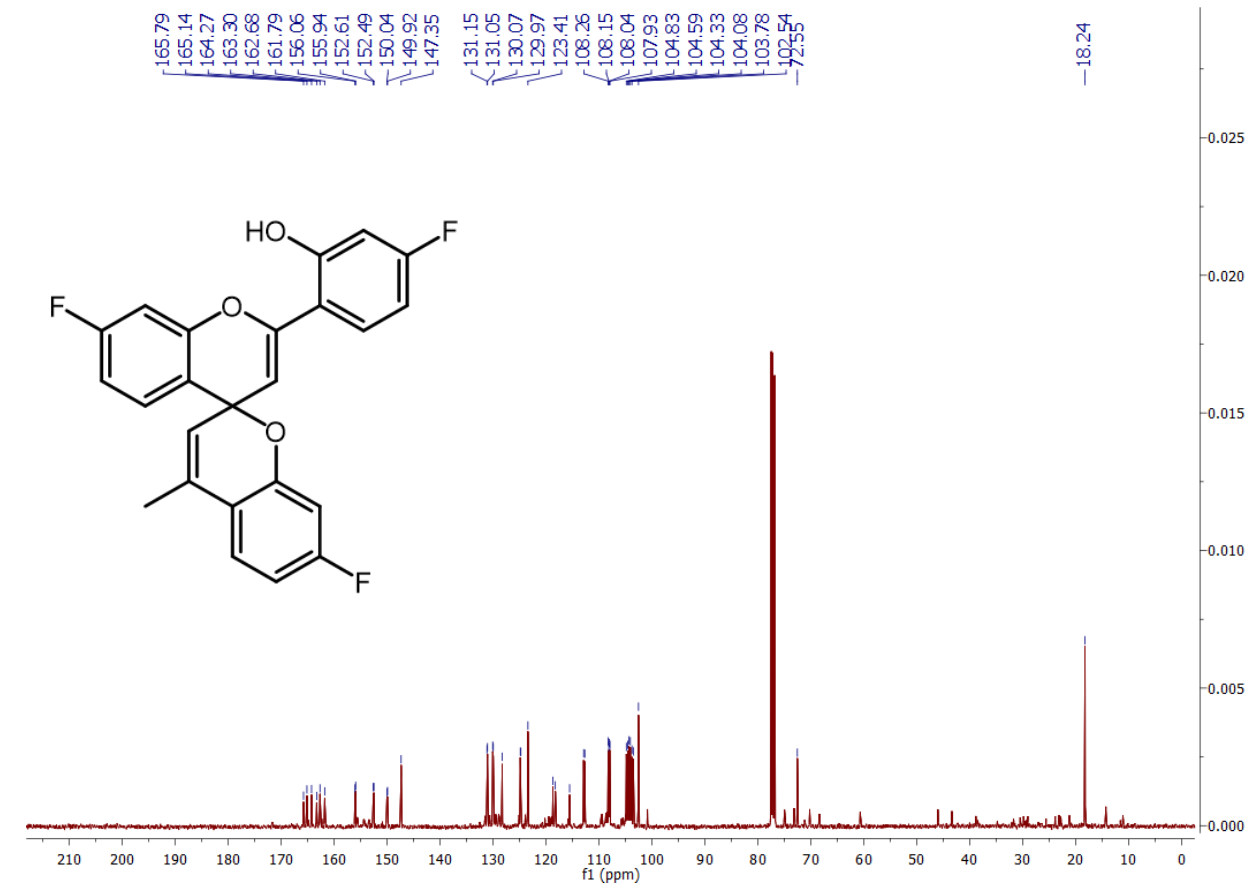

Figure S7. ${ }^{13} \mathrm{C}$ NMR spectrum $(100 \mathrm{MHz}, 298 \mathrm{~K})$ of isospiropyran 12 in $\mathrm{CDCl}_{3}$. 


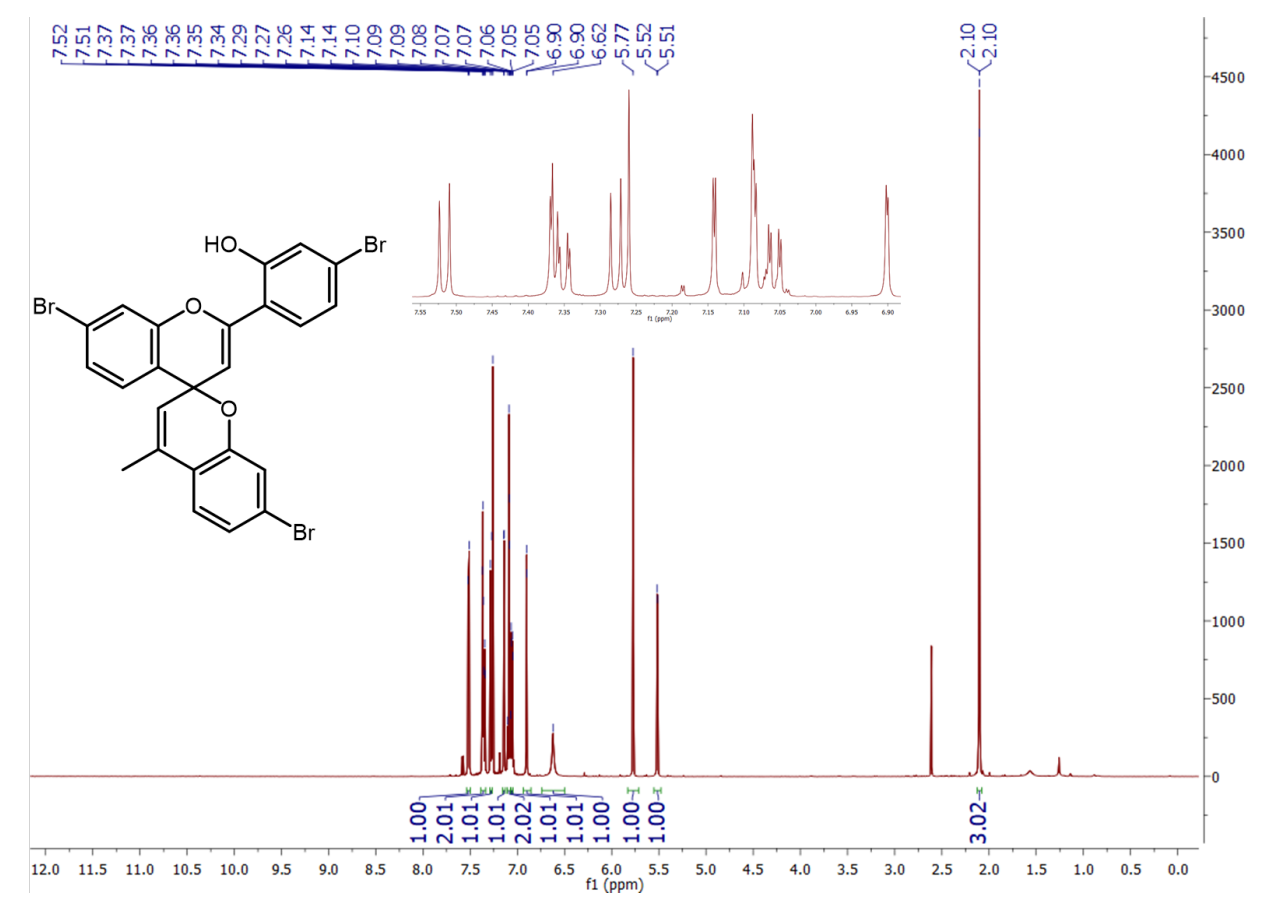

Figure S8. ${ }^{1} \mathrm{H}$ NMR spectrum $(600 \mathrm{MHz}, 298 \mathrm{~K})$ of isospiropyran 13 in $\mathrm{CDCl}_{3}$.

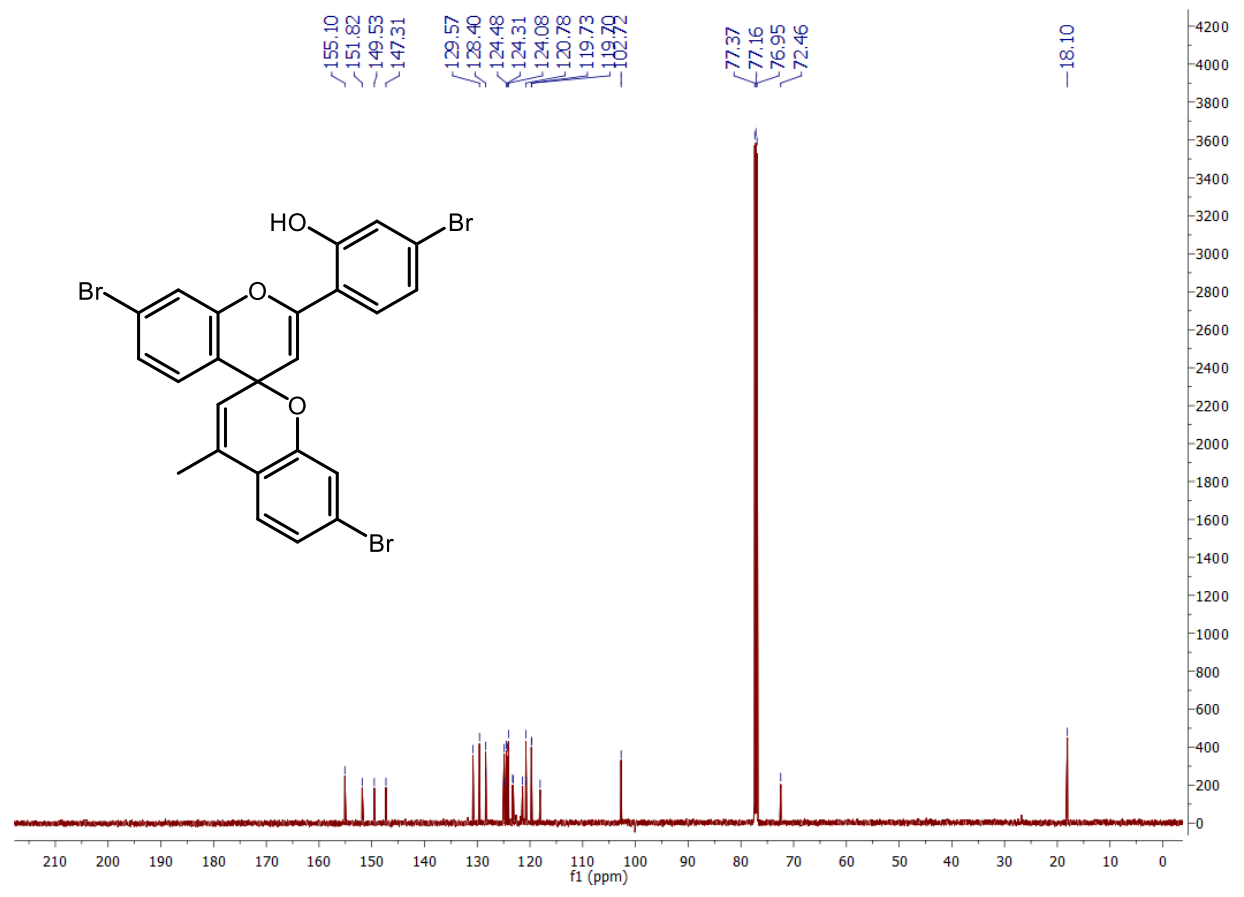

Figure S9. ${ }^{13} \mathrm{C}$ NMR spectrum $(150 \mathrm{MHz}, 298 \mathrm{~K})$ of isospiropyran 13 in $\mathrm{CDCl}_{3}$. 


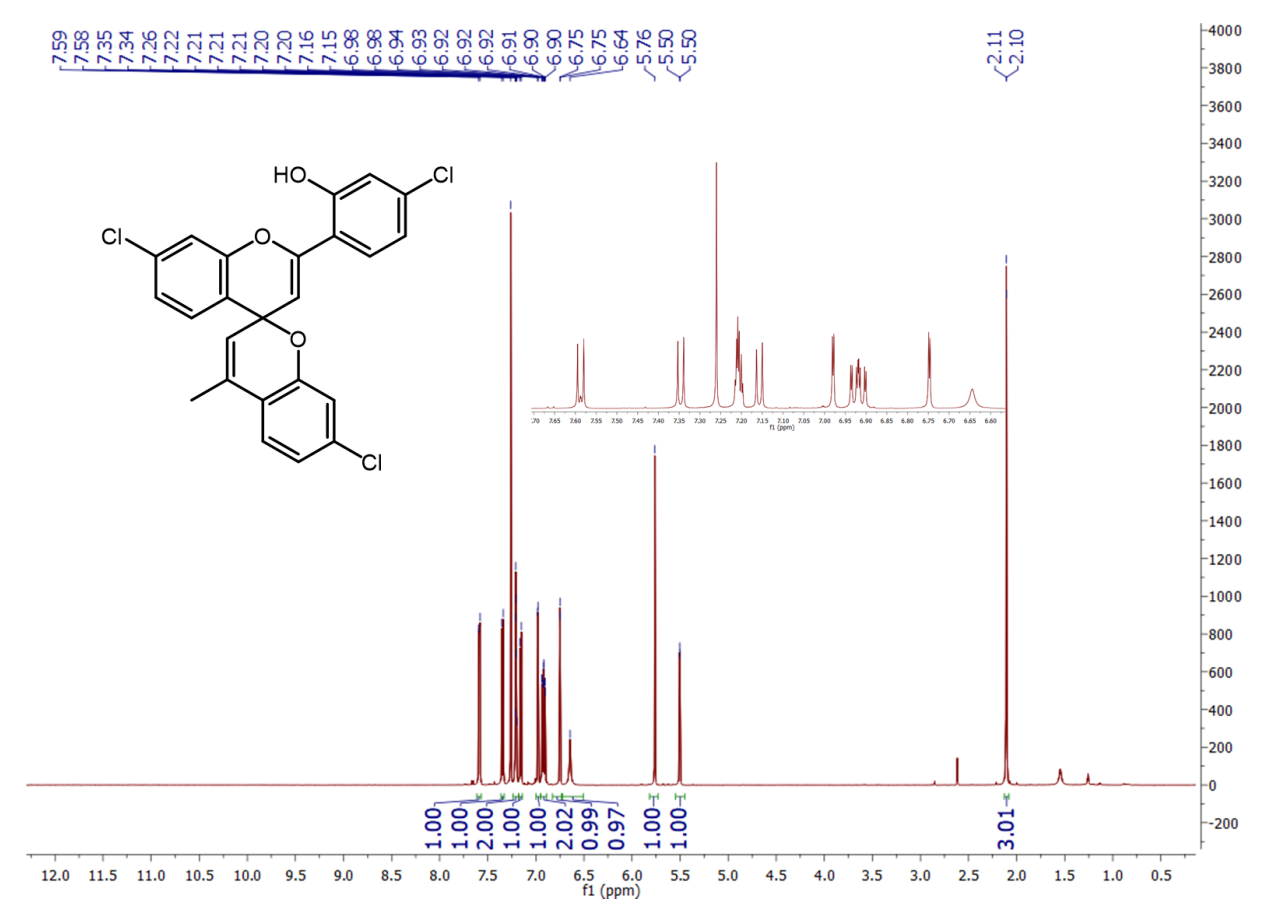

Figure S10. ${ }^{1} \mathrm{H}$ NMR spectrum $(600 \mathrm{MHz}, 298 \mathrm{~K})$ of isospiropyran 14 in $\mathrm{CDCl}_{3}$.

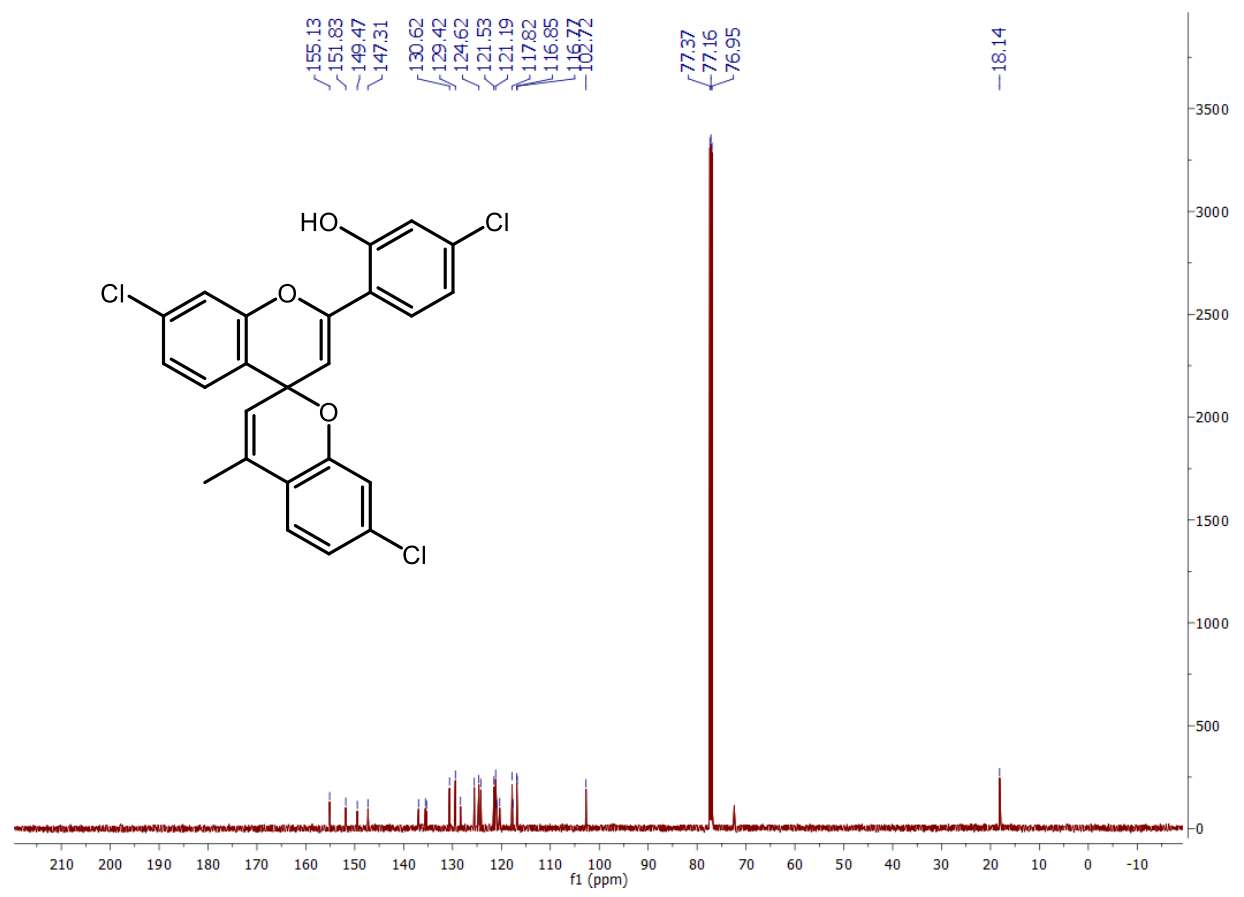

Figure S11. ${ }^{13} \mathrm{C}$ NMR spectrum $(150 \mathrm{MHz}, 298 \mathrm{~K})$ of isospiropyran 14 in $\mathrm{CDCl}_{3}$. 


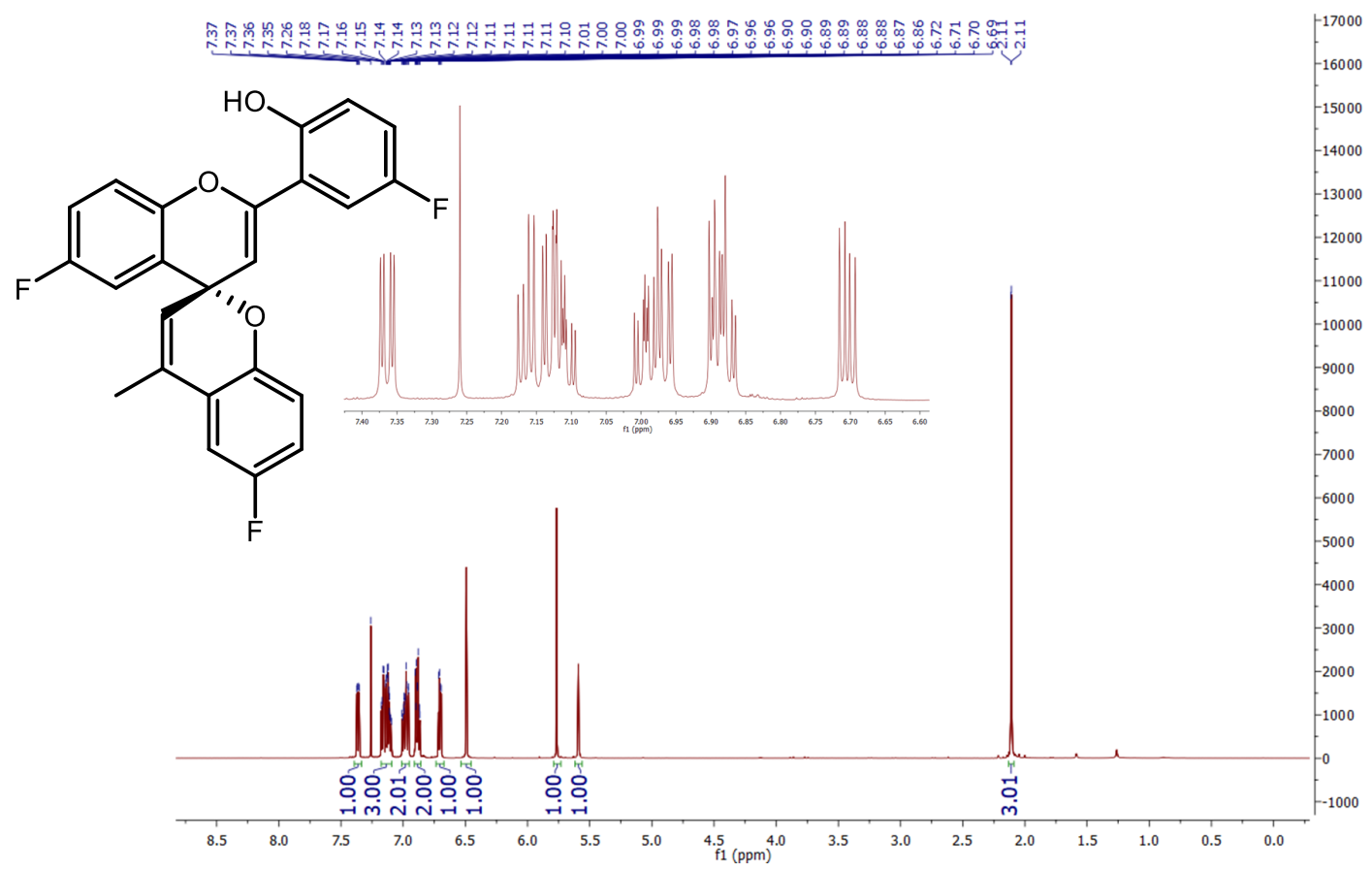

Figure S12. ${ }^{1} \mathrm{H}$ NMR spectrum $(600 \mathrm{MHz}, 298 \mathrm{~K})$ of isospiropyran 15 in $\mathrm{CDCl}_{3}$.

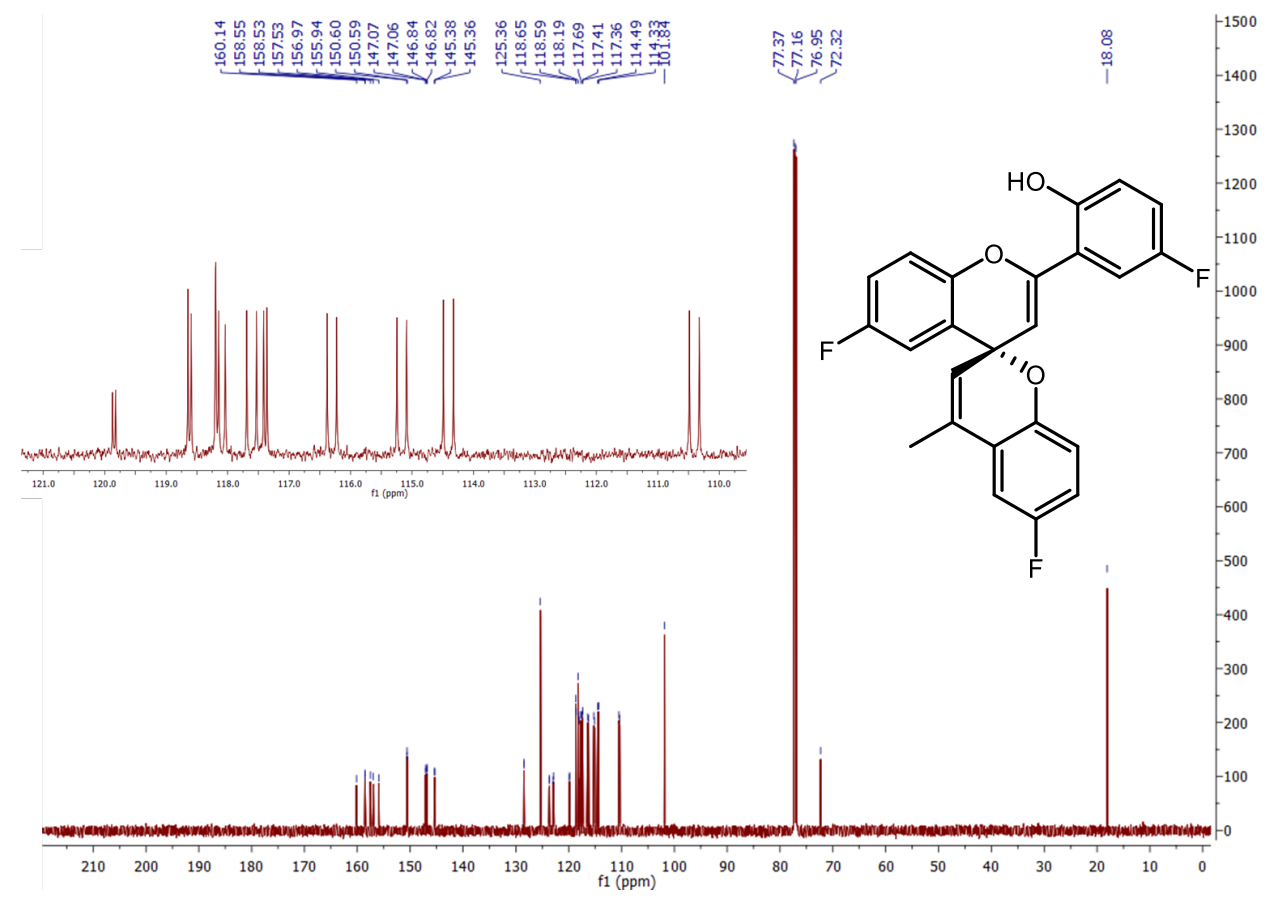

Figure S13. ${ }^{13} \mathrm{C}$ NMR spectrum $(150 \mathrm{MHz}, 298 \mathrm{~K})$ of isospiropyran 15 in $\mathrm{CDCl}_{3}$. 

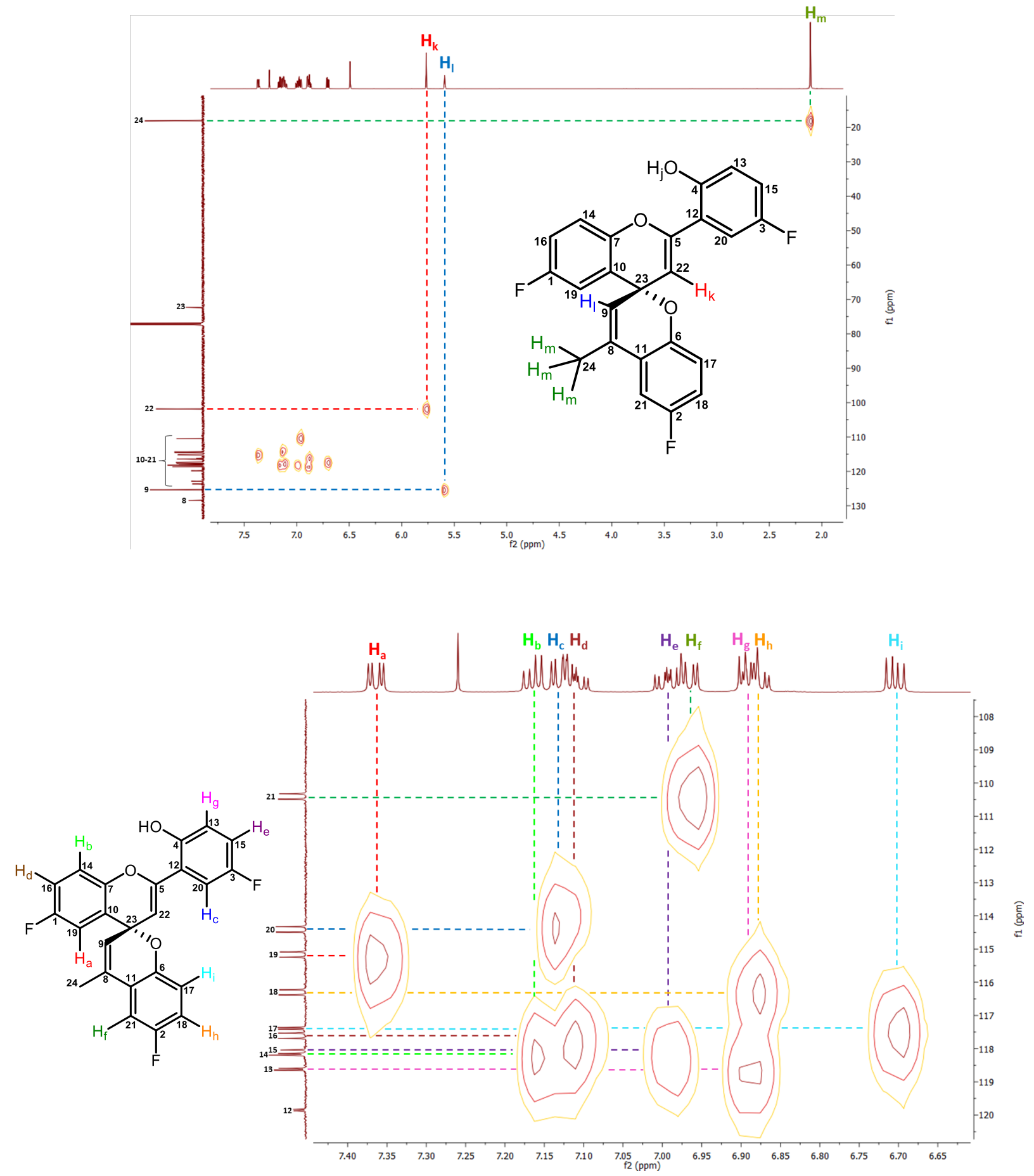

Figure S14. Two different regions of ${ }^{1} \mathrm{H}-{ }^{13} \mathrm{C}$ HSQC NMR (600 MHz, $298 \mathrm{~K}$ ) spectrum of isospiropyran 15 in $\mathrm{CDCl}_{3}$. 

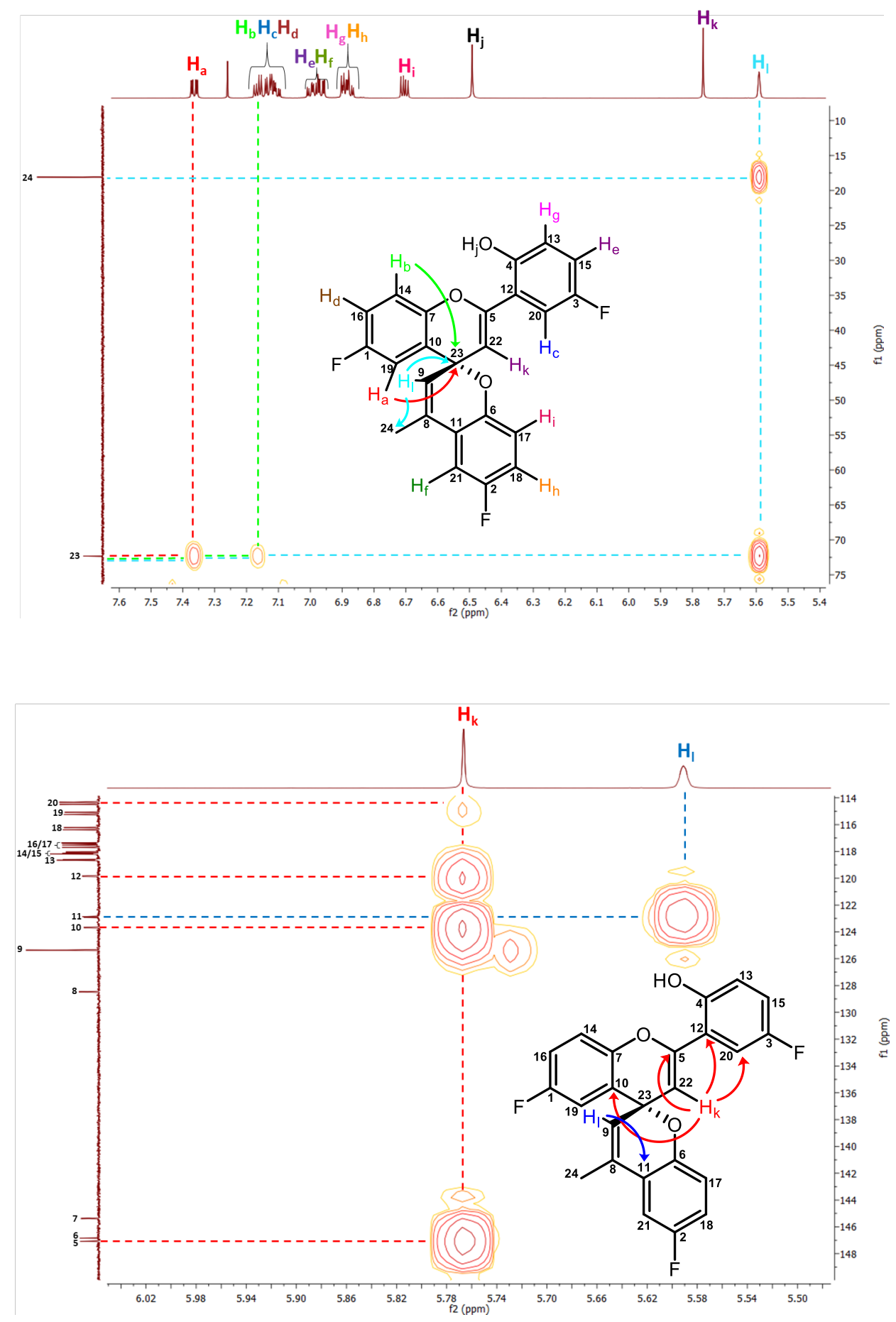

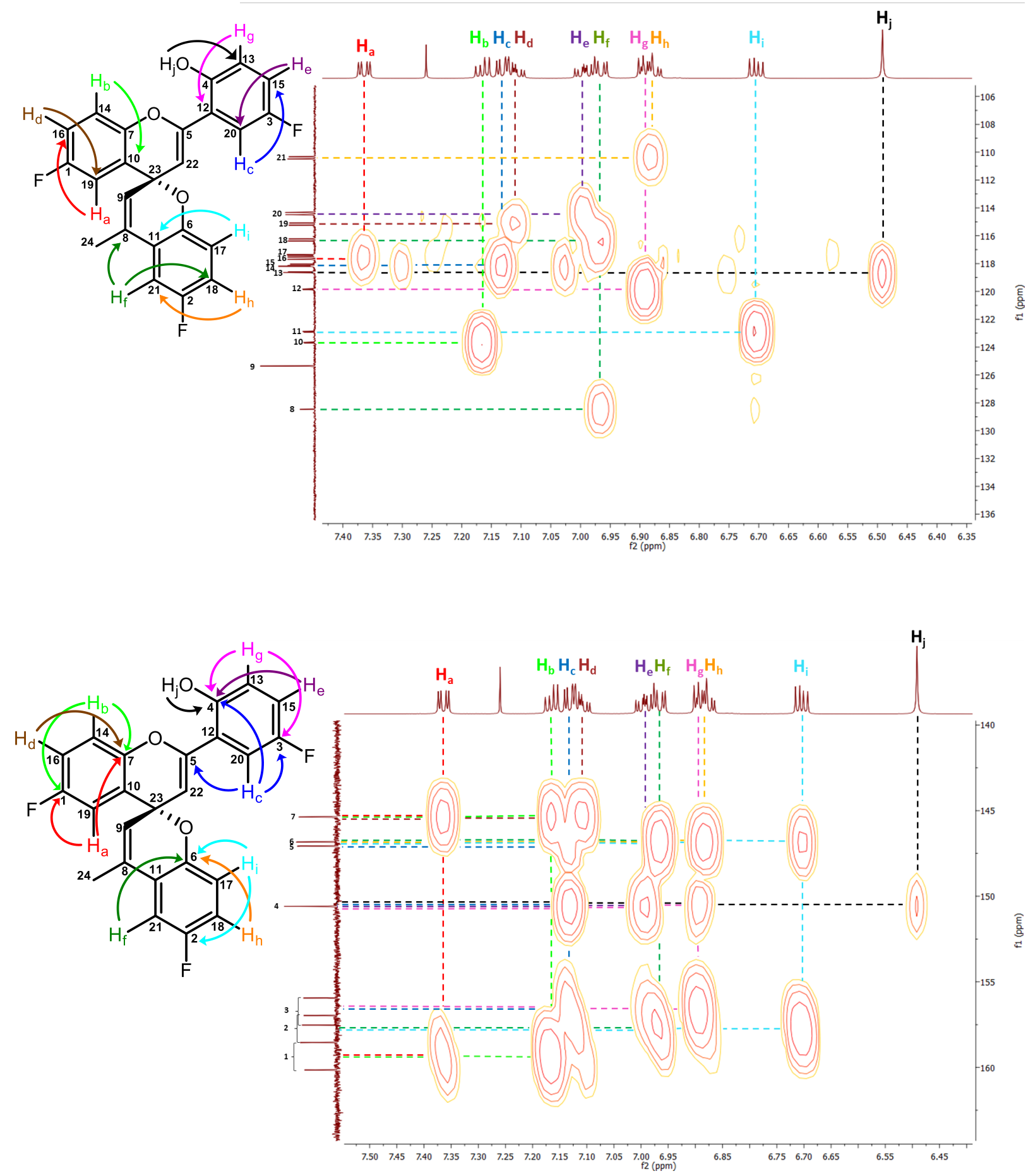

Figure S15. Four different regions of ${ }^{1} \mathrm{H}_{-}{ }^{13} \mathrm{C}$ HMBC NMR $(600 \mathrm{MHz}, 298 \mathrm{~K})$ spectrum of isospiropyran 15 in $\mathrm{CDCl}_{3}$. 


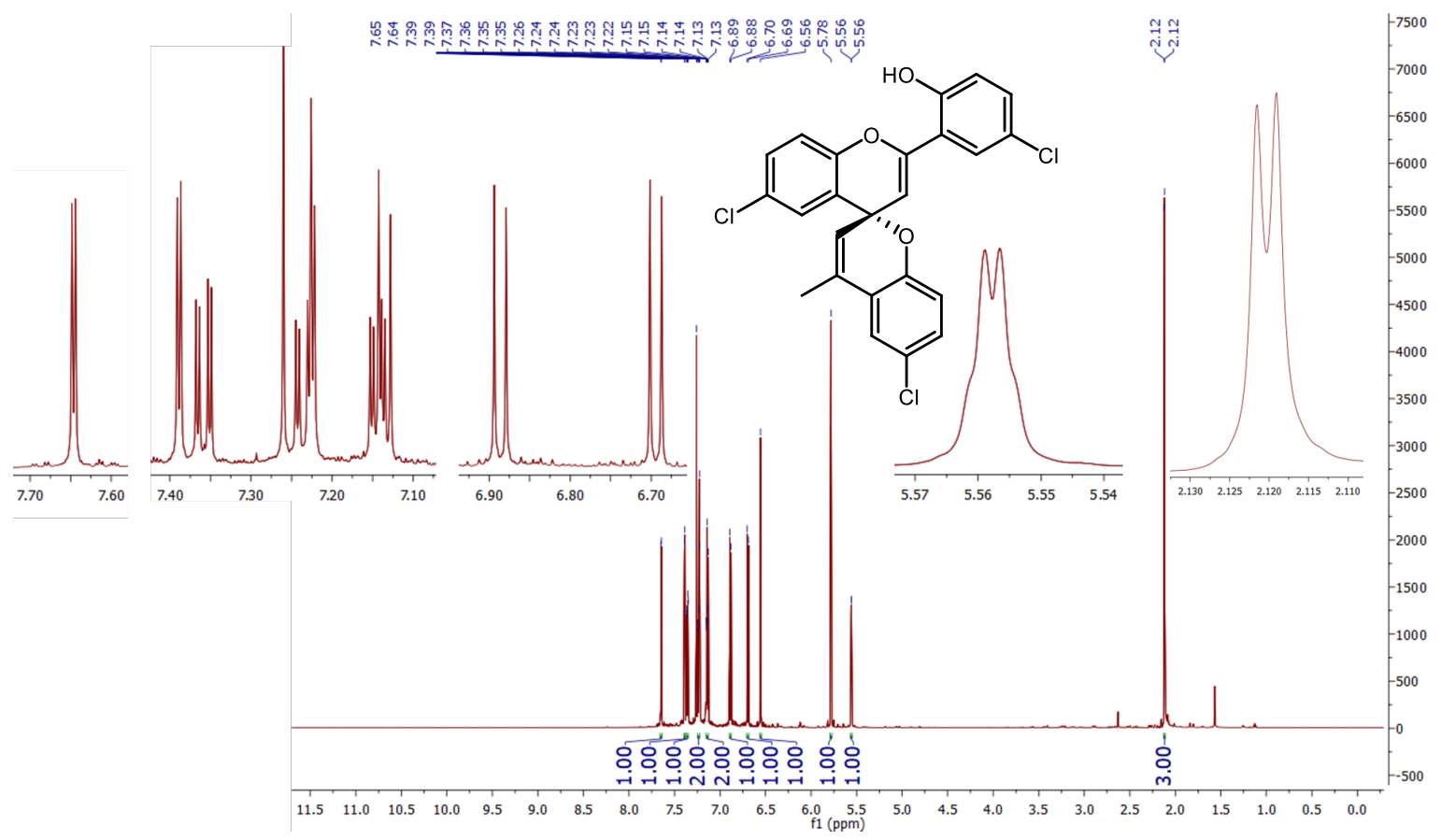

Figure S16. ${ }^{1} \mathrm{H}$ NMR spectrum $(600 \mathrm{MHz}, 298 \mathrm{~K})$ of isospiropyran 16 in $\mathrm{CDCl}_{3}$.

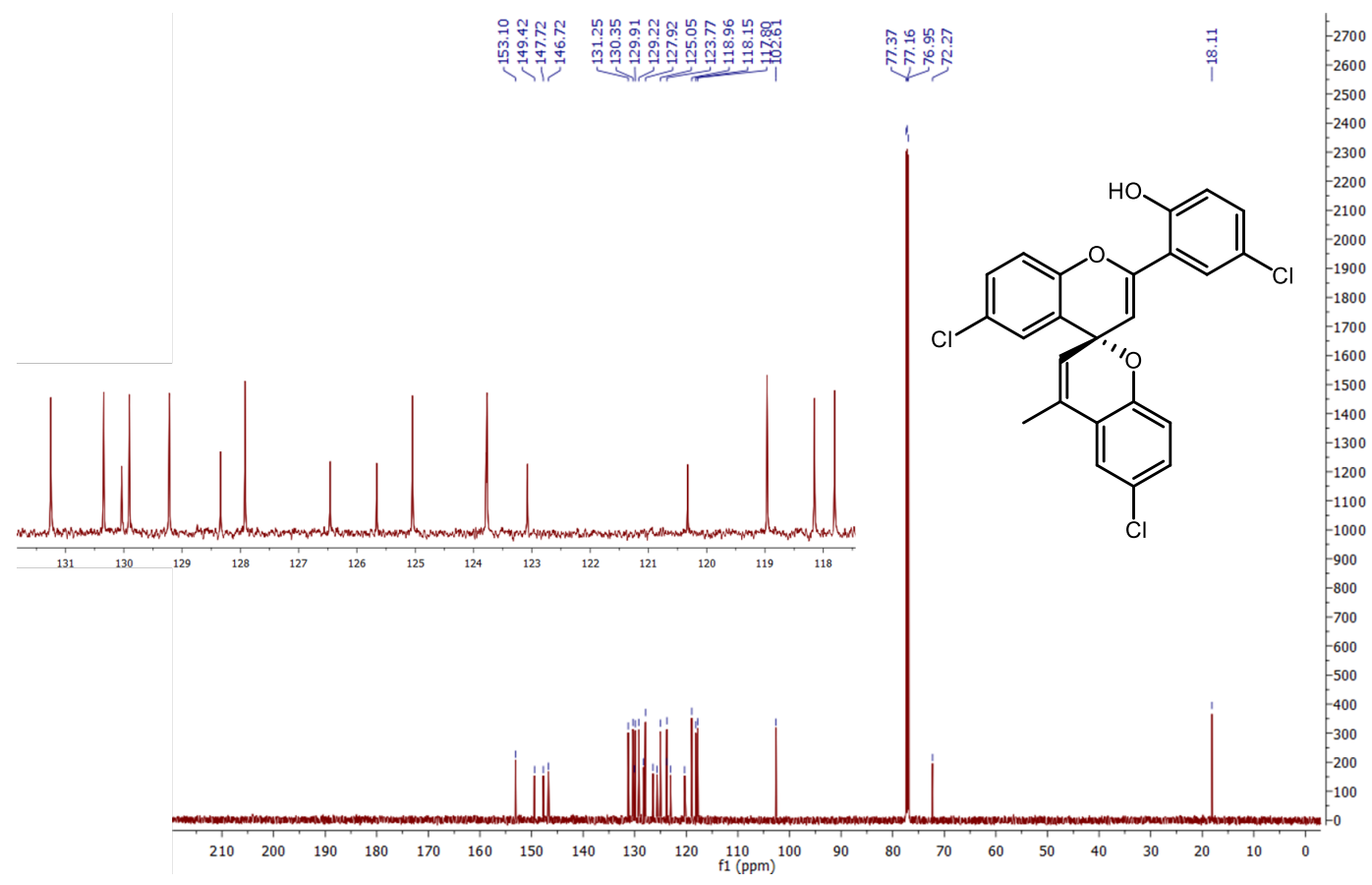

Figure S17. ${ }^{13} \mathrm{C}$ NMR spectrum $(150 \mathrm{MHz}, 298 \mathrm{~K})$ of isospiropyran 16 in $\mathrm{CDCl}_{3}$. 


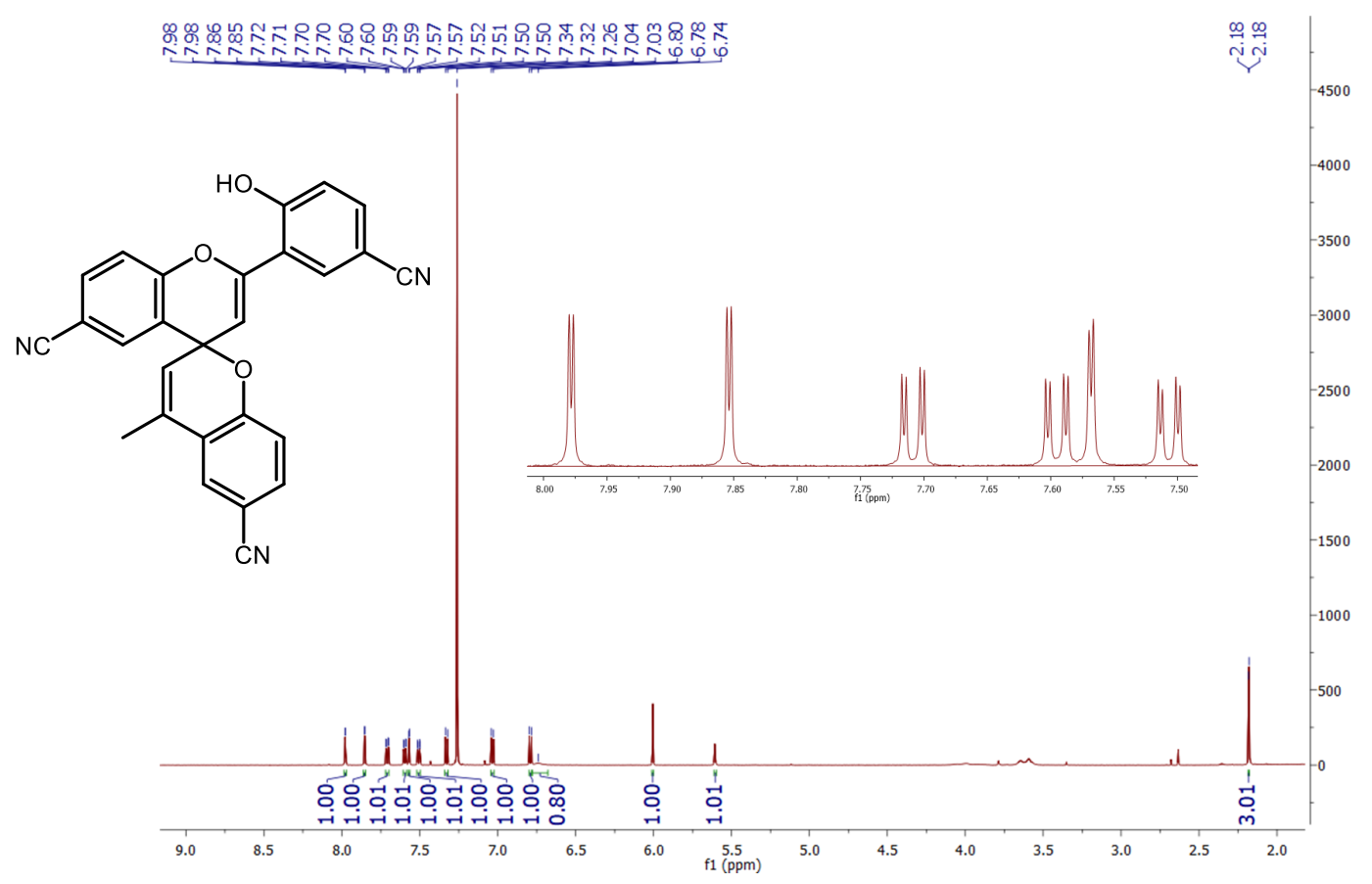

Figure S18. ${ }^{1} \mathrm{H}$ NMR spectrum $(600 \mathrm{MHz}, 298 \mathrm{~K})$ of isospiropyran 18 in $\mathrm{CDCl}_{3}$.

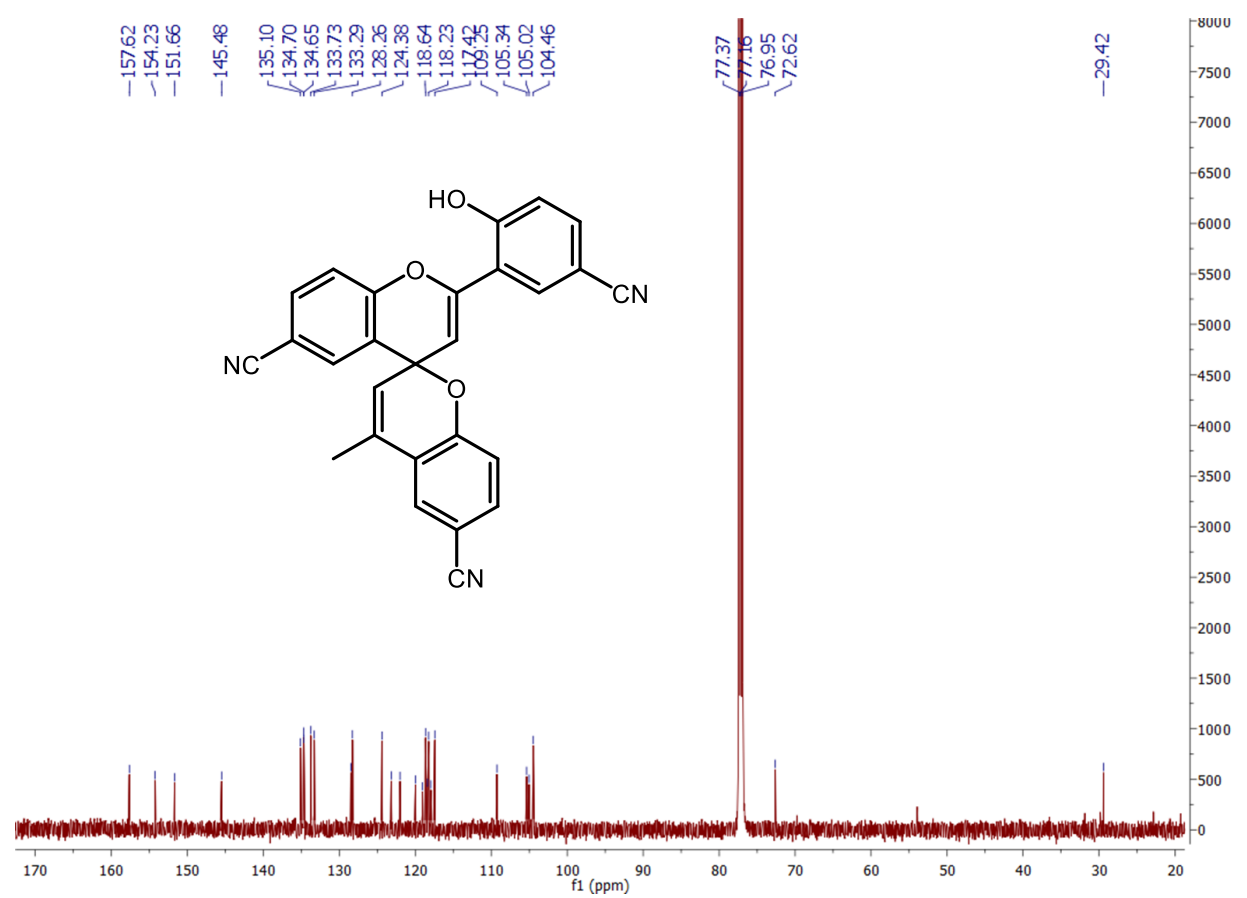

Figure S19. ${ }^{13} \mathrm{C}$ NMR spectrum $(150 \mathrm{MHz}, 298 \mathrm{~K})$ of isospiropyran 18 in $\mathrm{CDCl}_{3}$. 


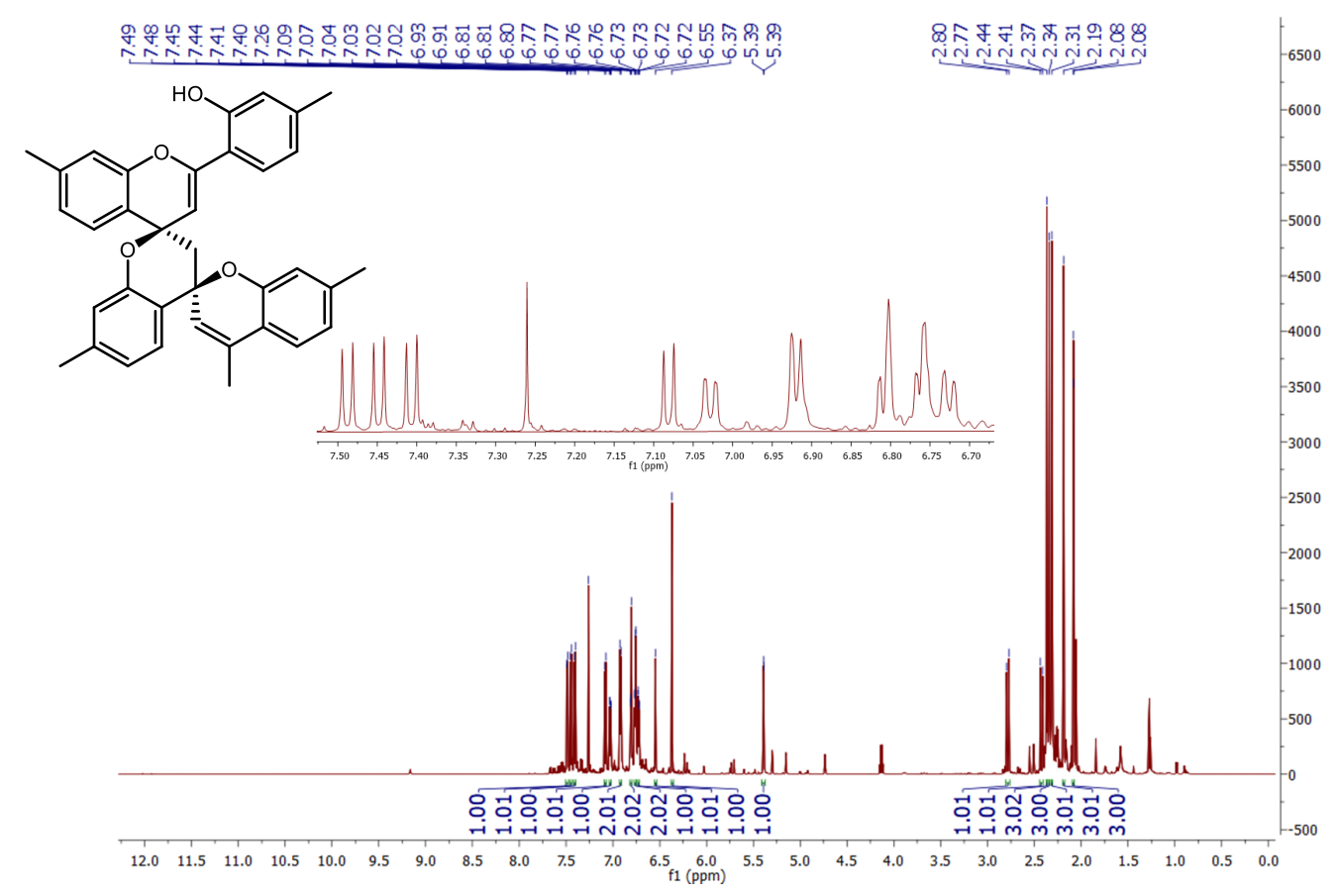

Figure S20. ${ }^{1} \mathrm{H}$ NMR spectrum (600 MHz, $\left.298 \mathrm{~K}\right)$ of compound 30 in $\mathrm{CDCl}_{3}$.

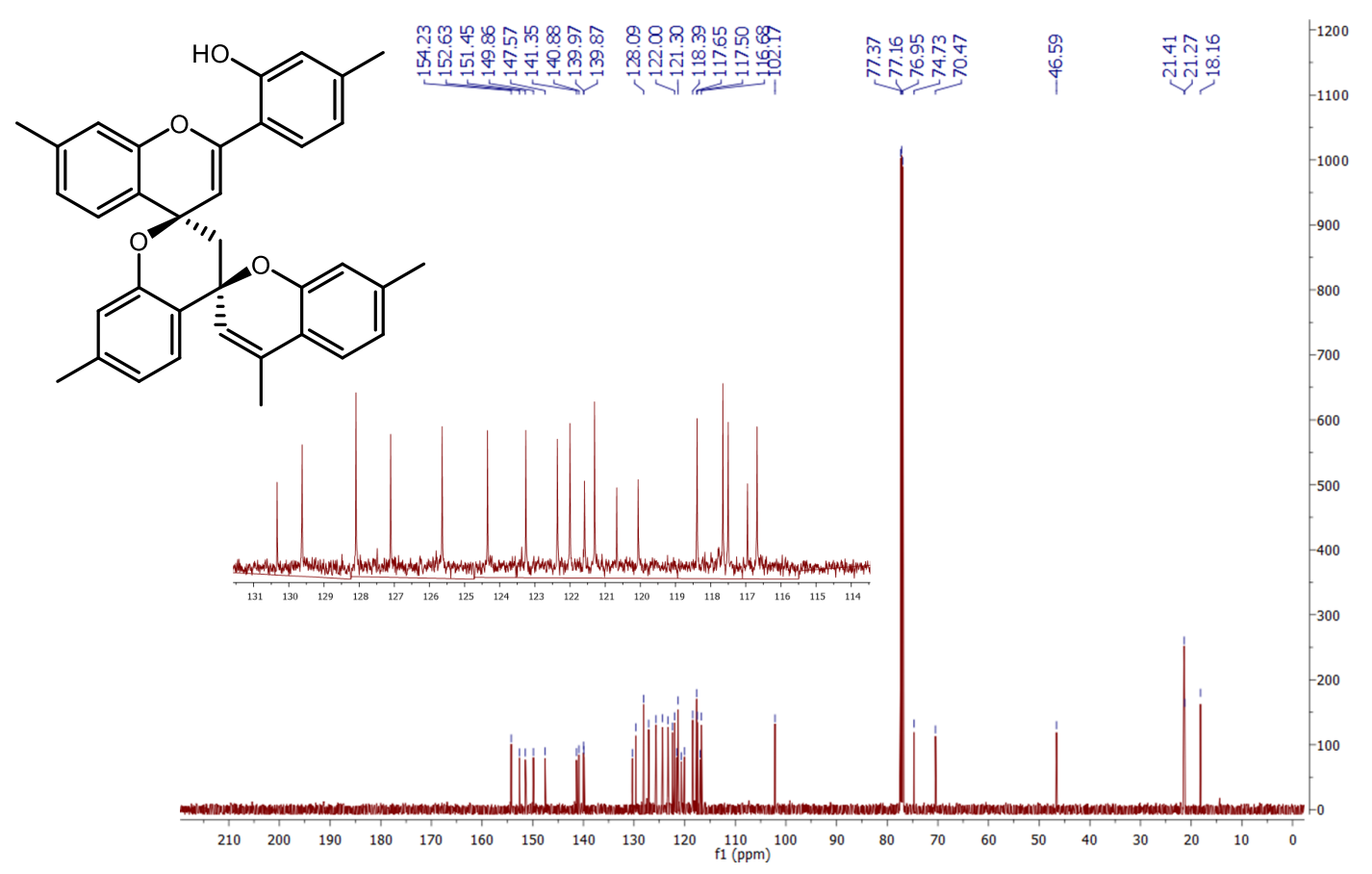

Figure S21. ${ }^{13} \mathrm{C}$ NMR spectrum $(150 \mathrm{MHz}, 298 \mathrm{~K})$ of compound 30 in $\mathrm{CDCl}_{3}$. 


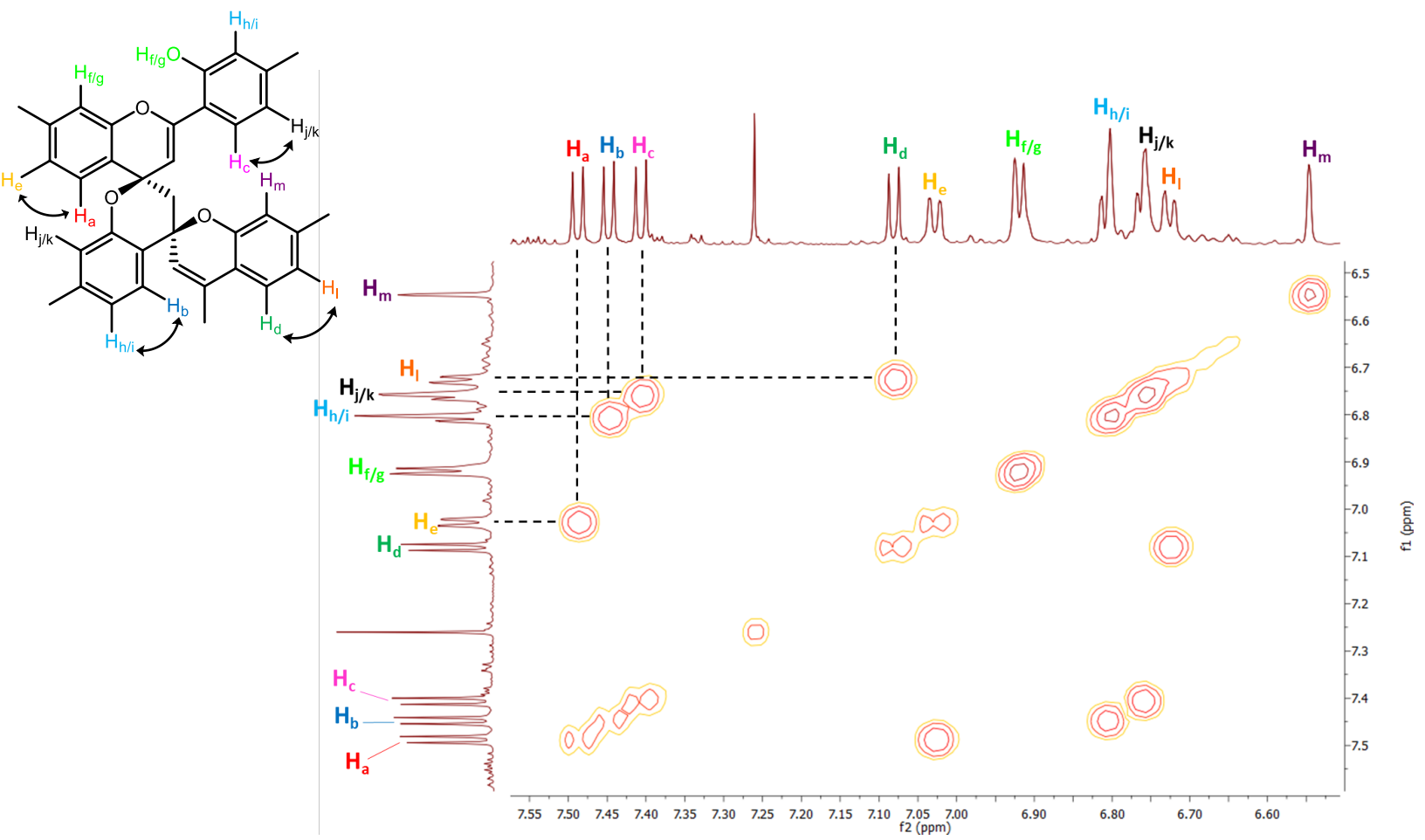

Figure S22. ${ }^{1} \mathrm{H}-{ }^{1} \mathrm{H}$ COSY NMR $(600 \mathrm{MHz}, 298 \mathrm{~K})$ spectrum of compound 30 in $\mathrm{CDCl}_{3}$.

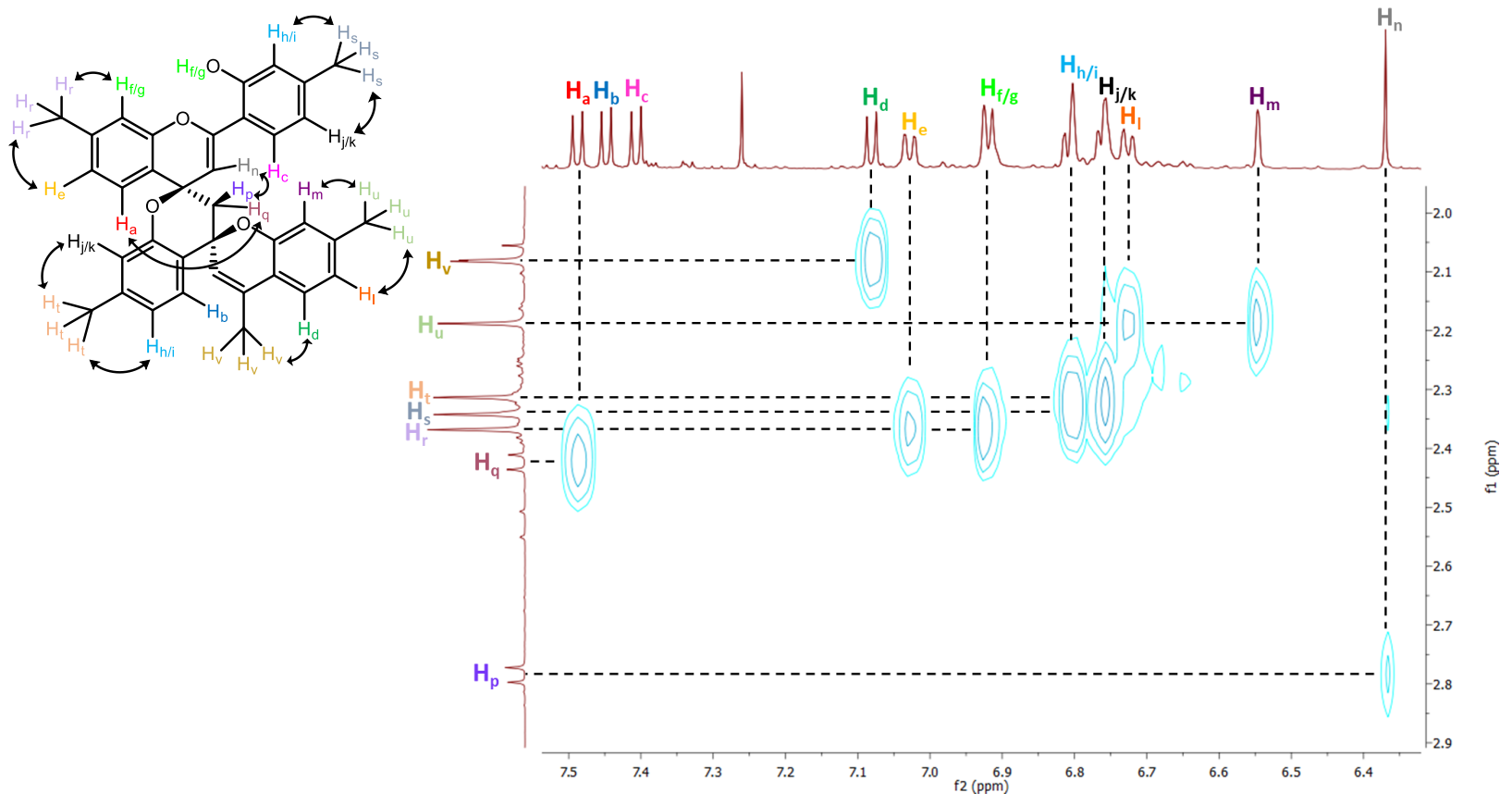




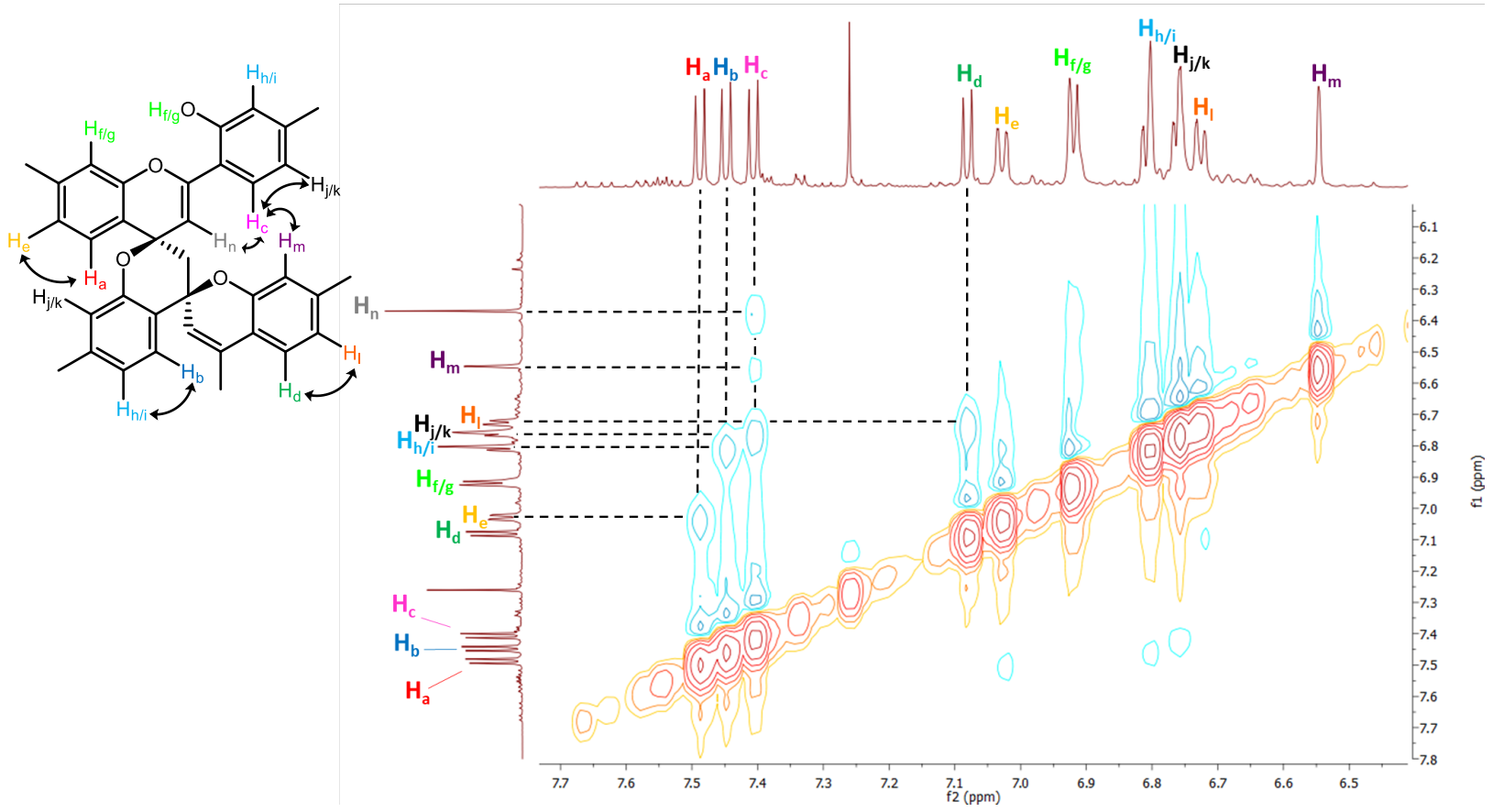

Figure S23. Two different regions of ${ }^{1} \mathrm{H}-{ }^{1} \mathrm{H}$ NOESY NMR (600 MHz, $\left.298 \mathrm{~K}\right)$ spectrum of tetramer 30 in $\mathrm{CDCl}_{3}$.

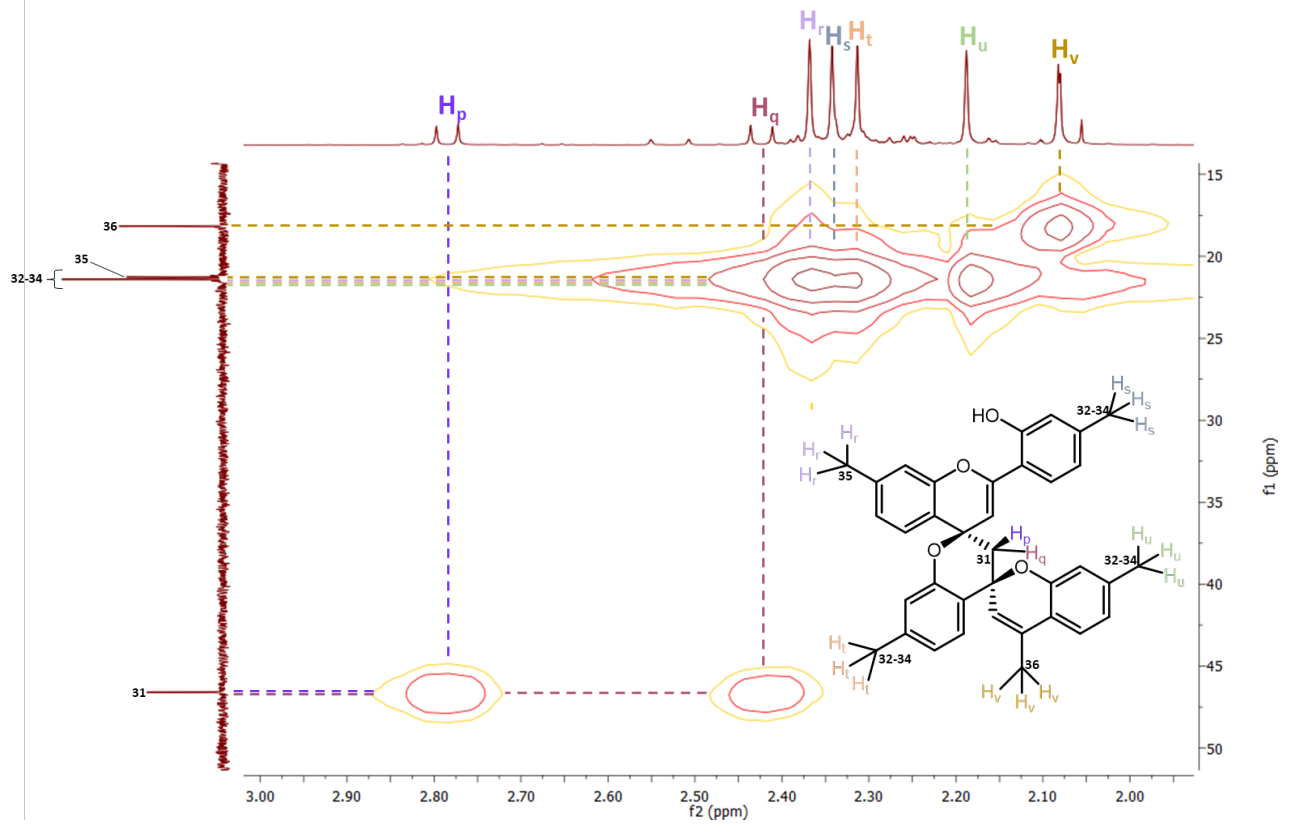




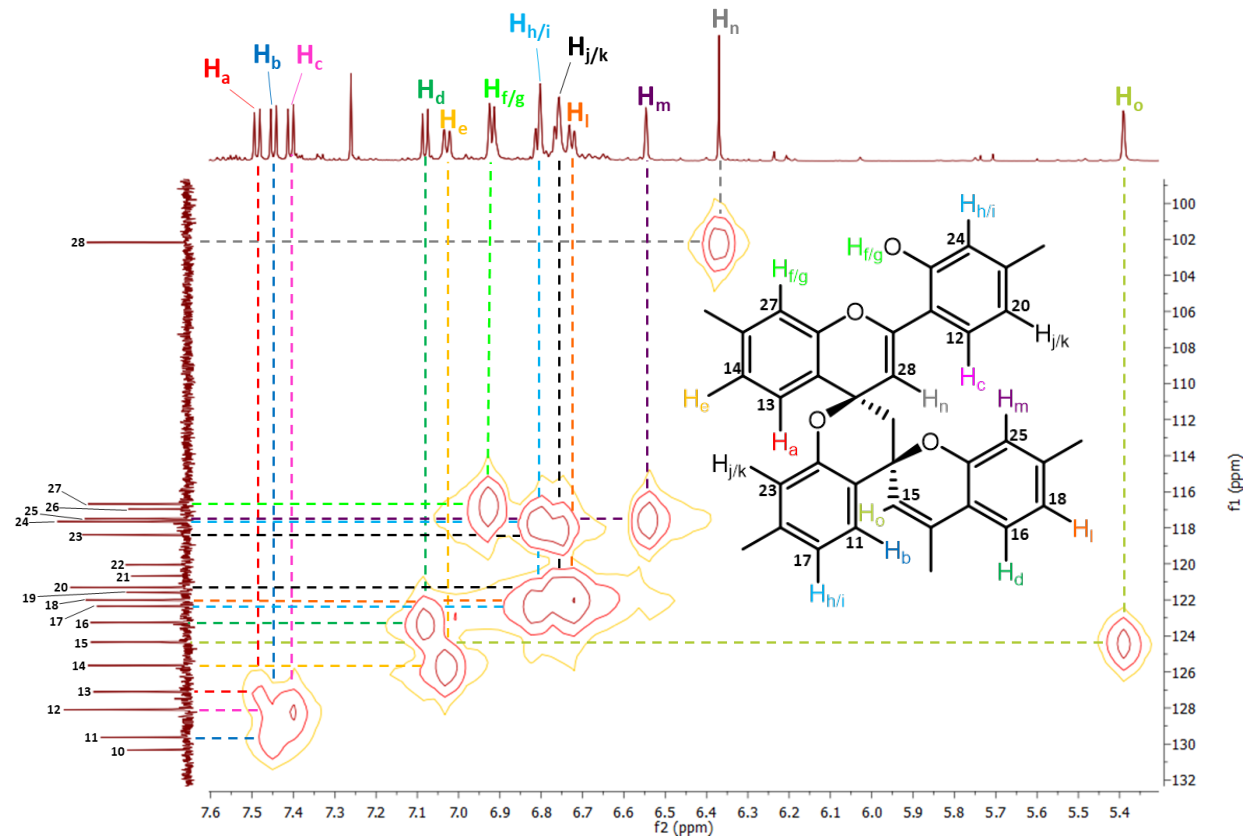

Figure S24. Two different regions of ${ }^{1} \mathrm{H}-{ }^{13} \mathrm{C}$ HSQC NMR (600 MHz, $298 \mathrm{~K}$ ) spectrum of tetramer 30 in $\mathrm{CDCl}_{3}$.

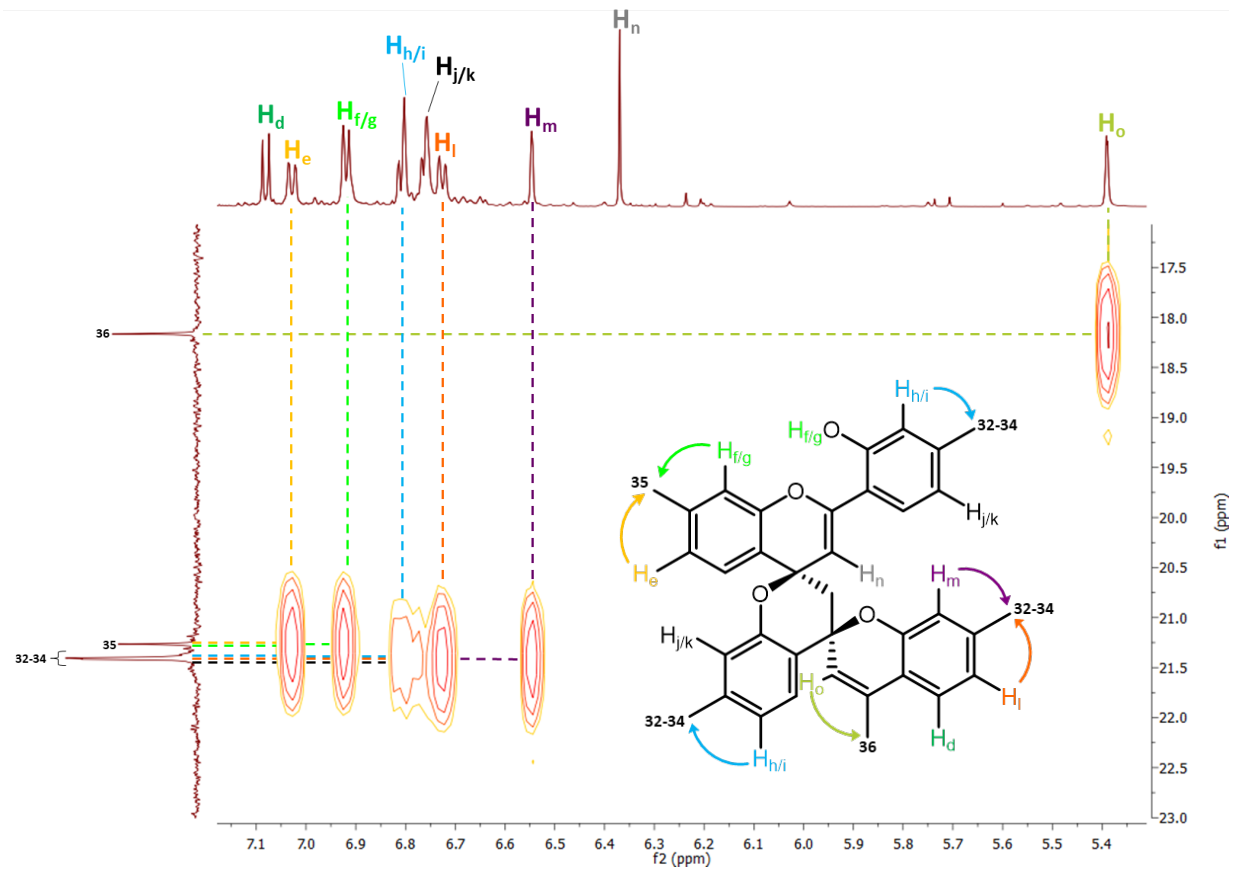



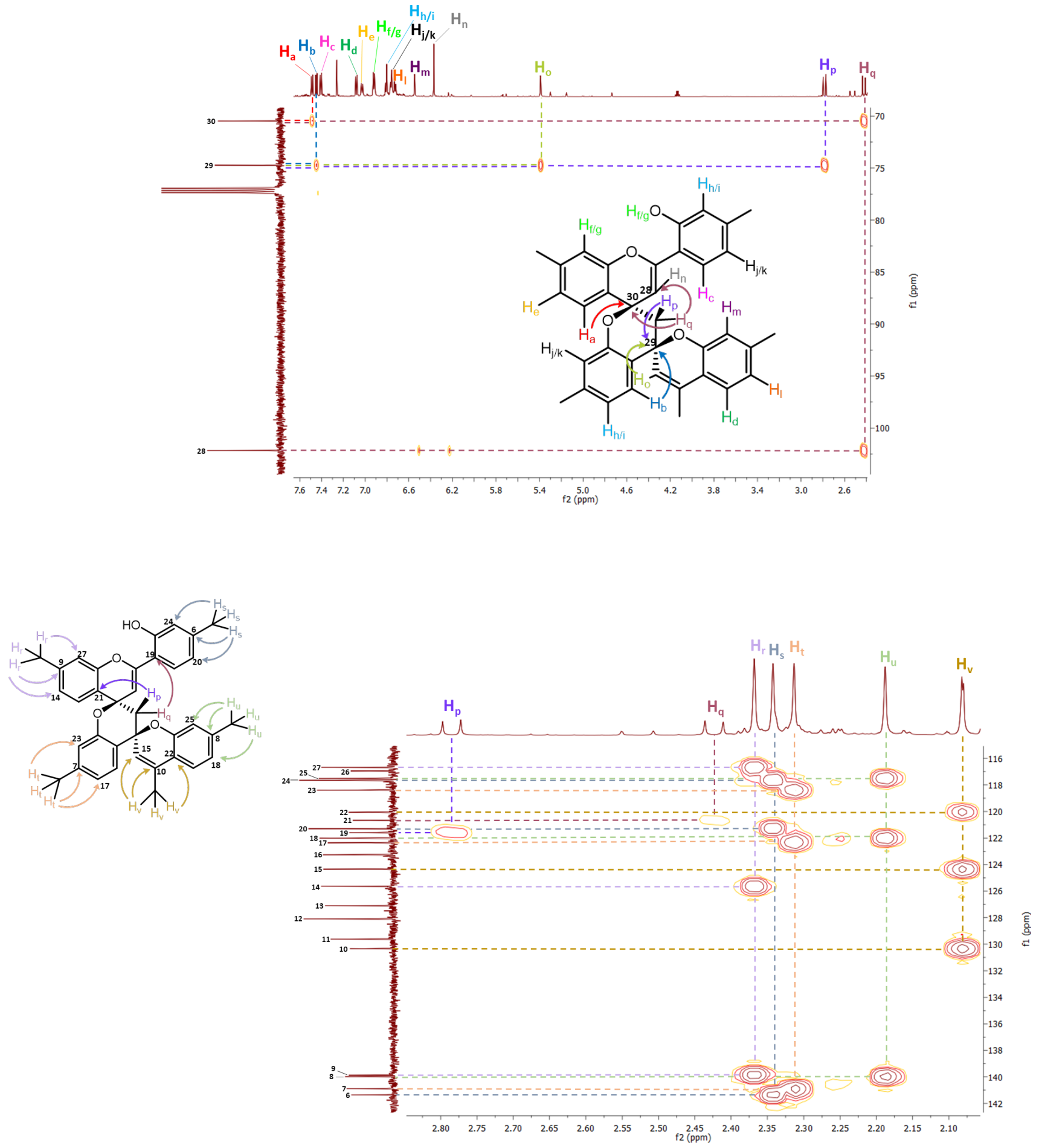

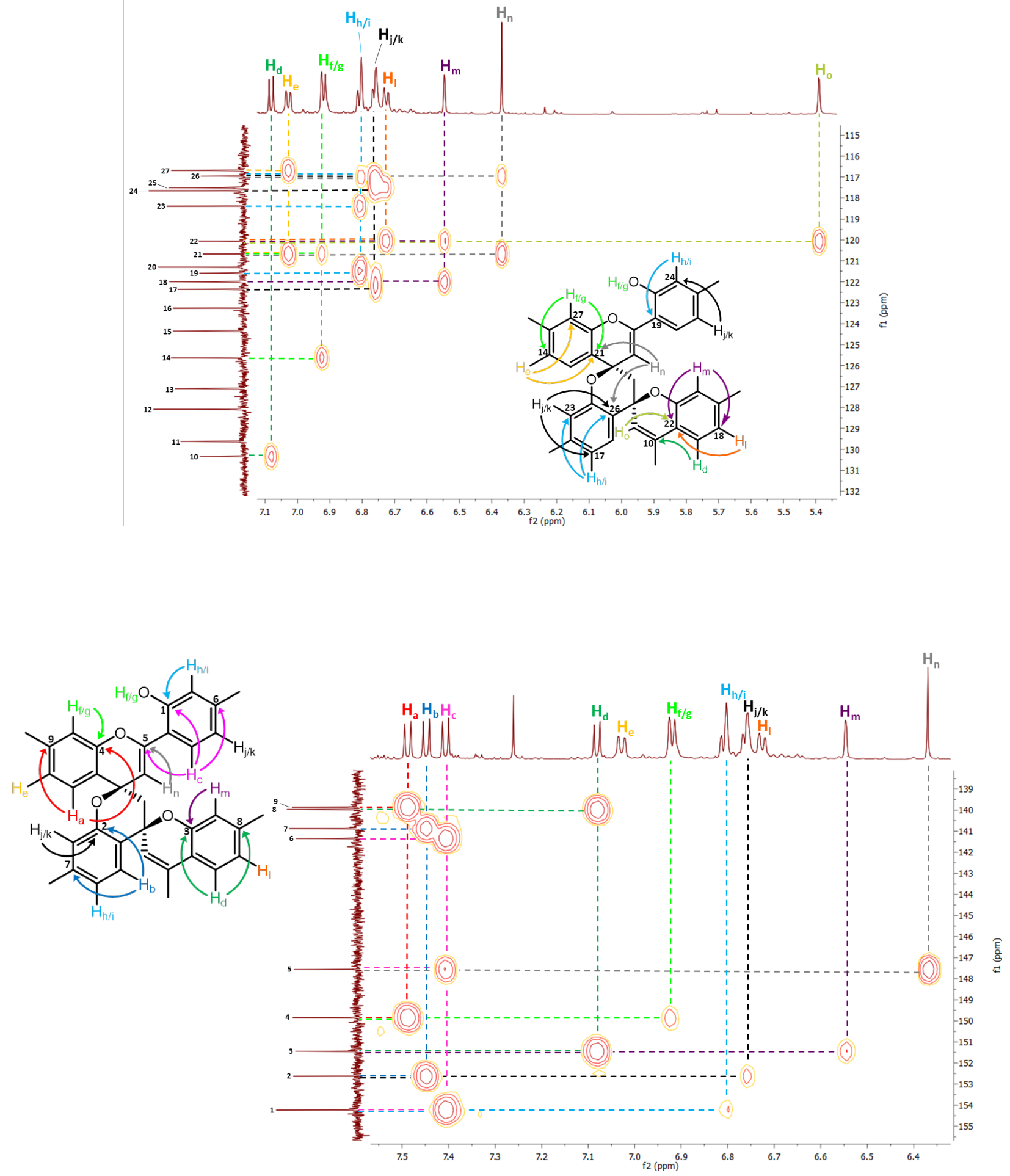

Figure S25. Five different regions of ${ }^{1} \mathrm{H}^{-13} \mathrm{C} \mathrm{HMBC}$ NMR (600 MHz, $\left.298 \mathrm{~K}\right)$ spectrum of tetramer 30 in $\mathrm{CDCl}_{3}$. 


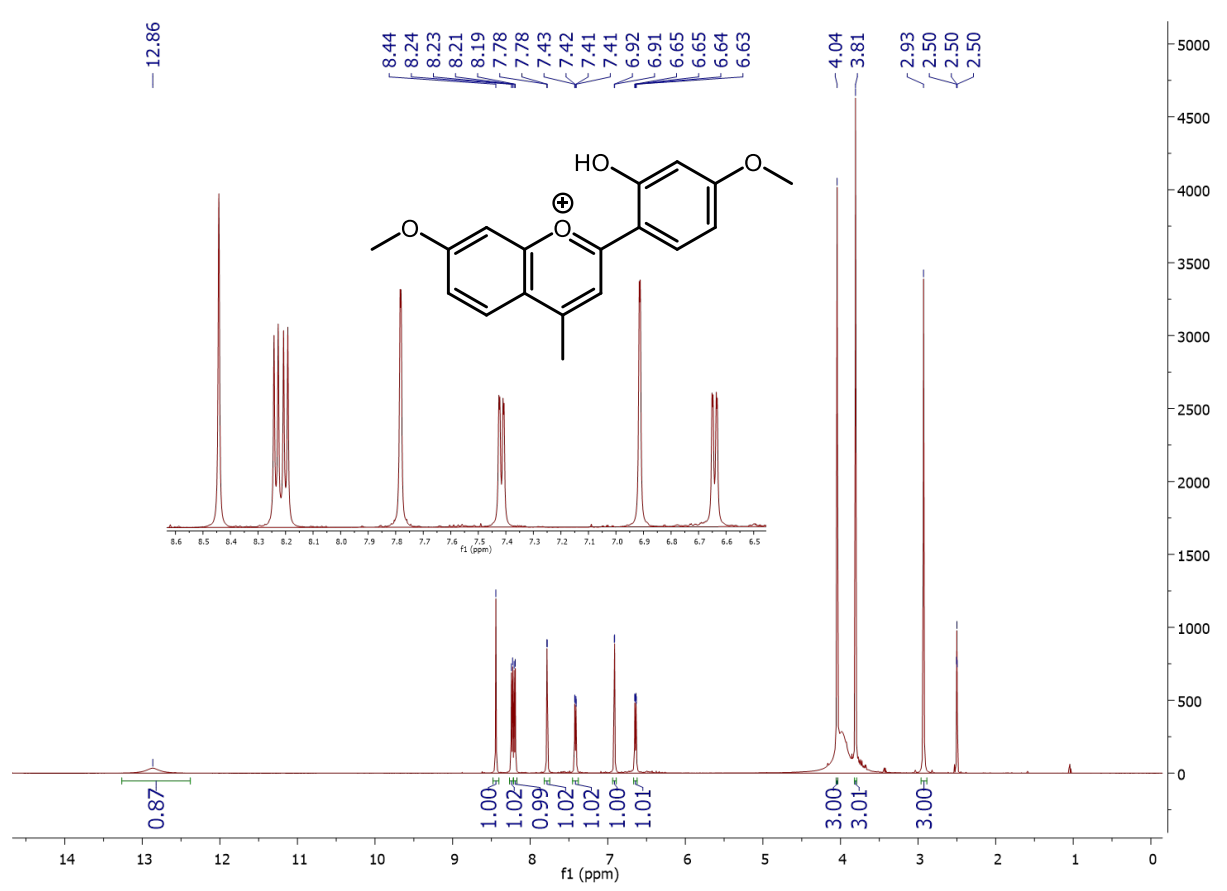

Figure S26. ${ }^{1} \mathrm{H}$ NMR spectrum $(600 \mathrm{MHz}, 298 \mathrm{~K})$ of anthocyanidin 31 in $d_{6}$-DMSO.

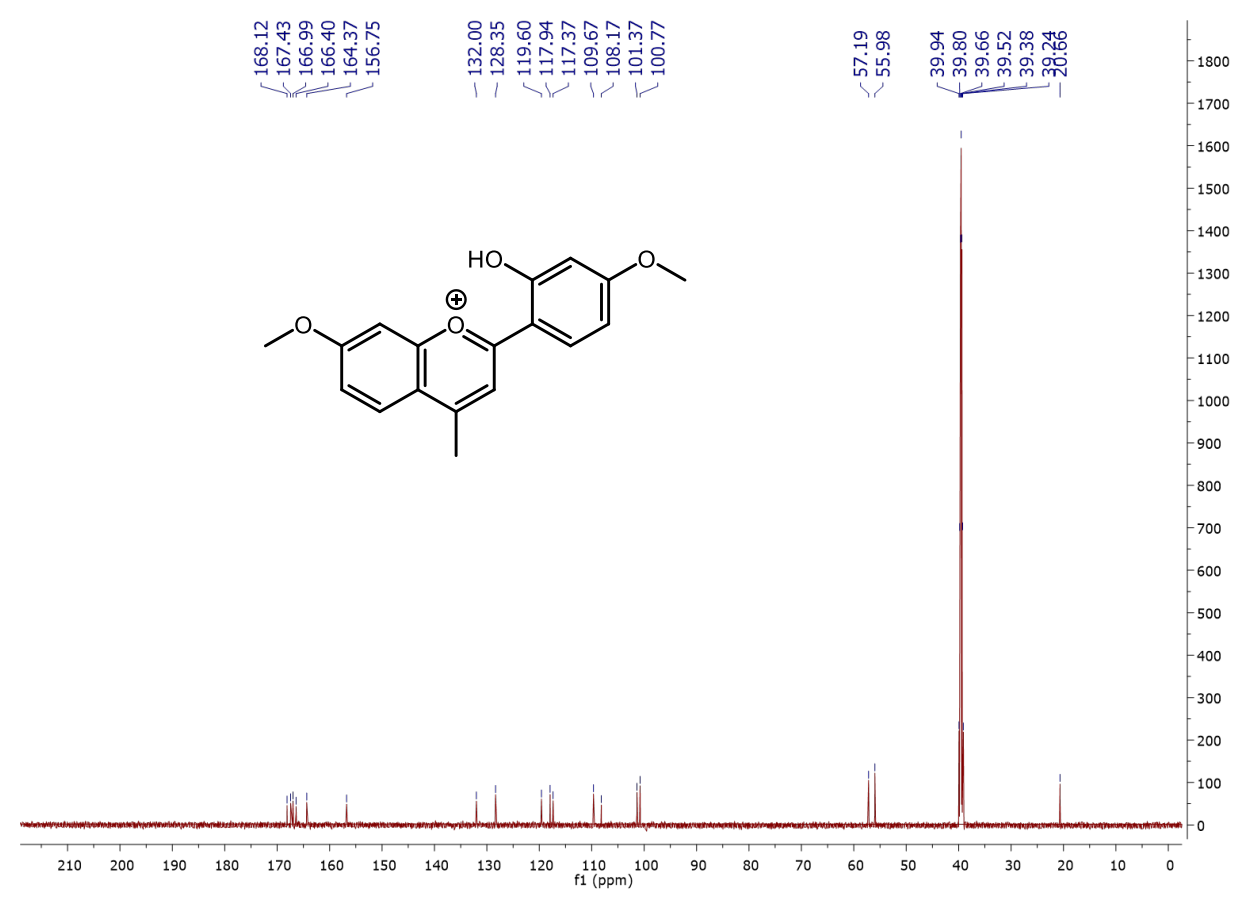

Figure S27. ${ }^{13} \mathrm{C}$ NMR spectrum $(150 \mathrm{MHz}, 298 \mathrm{~K})$ of anthocyanidin 31 in $d_{6}$-DMSO. 


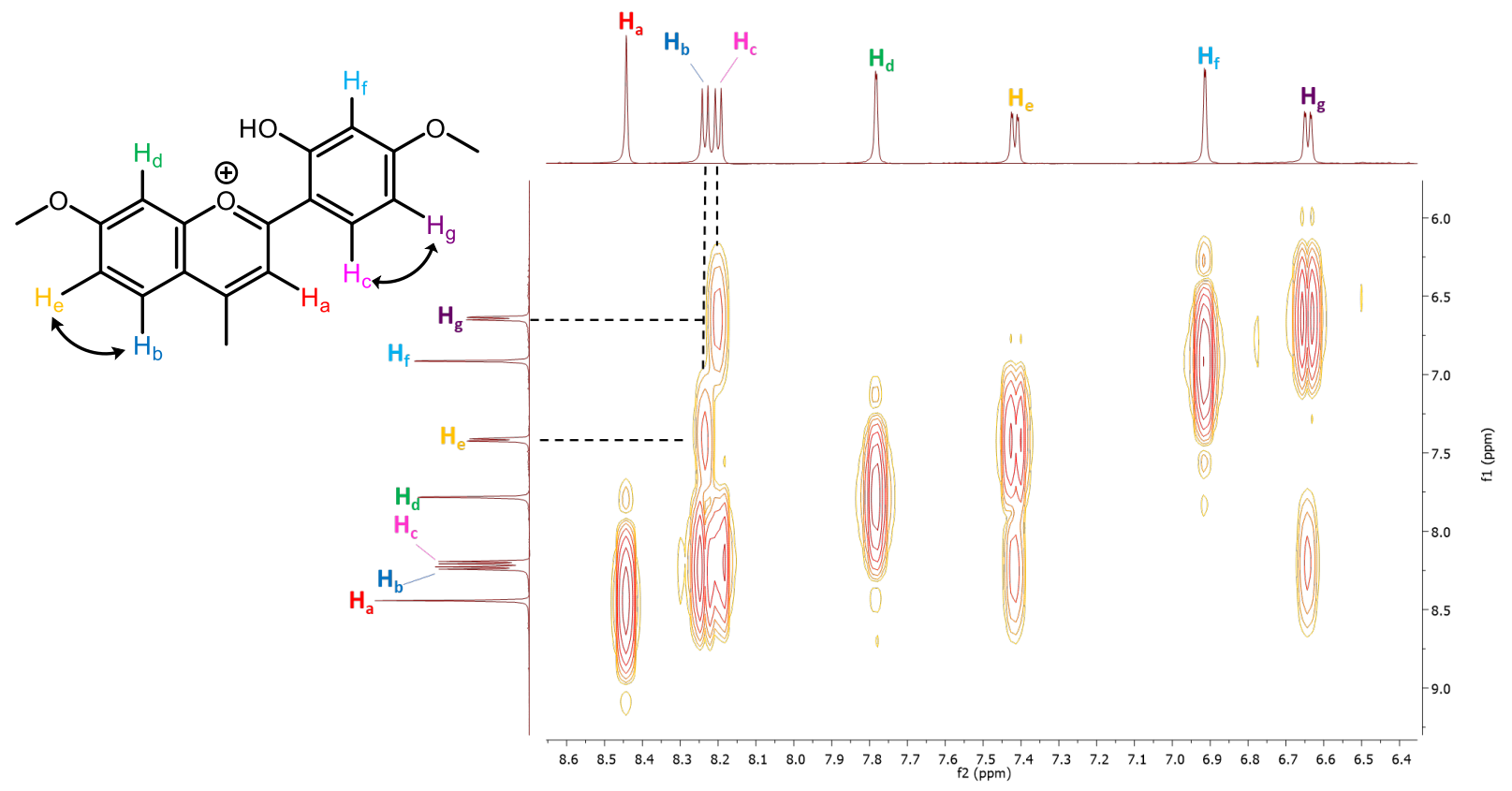

Figure S28. ${ }^{1} \mathrm{H}-{ }^{1} \mathrm{H}$ COSY NMR $(600 \mathrm{MHz}, 298 \mathrm{~K})$ spectrum of anthocyanidin $\mathbf{3 1}$ in $d_{6}$-DMSO.

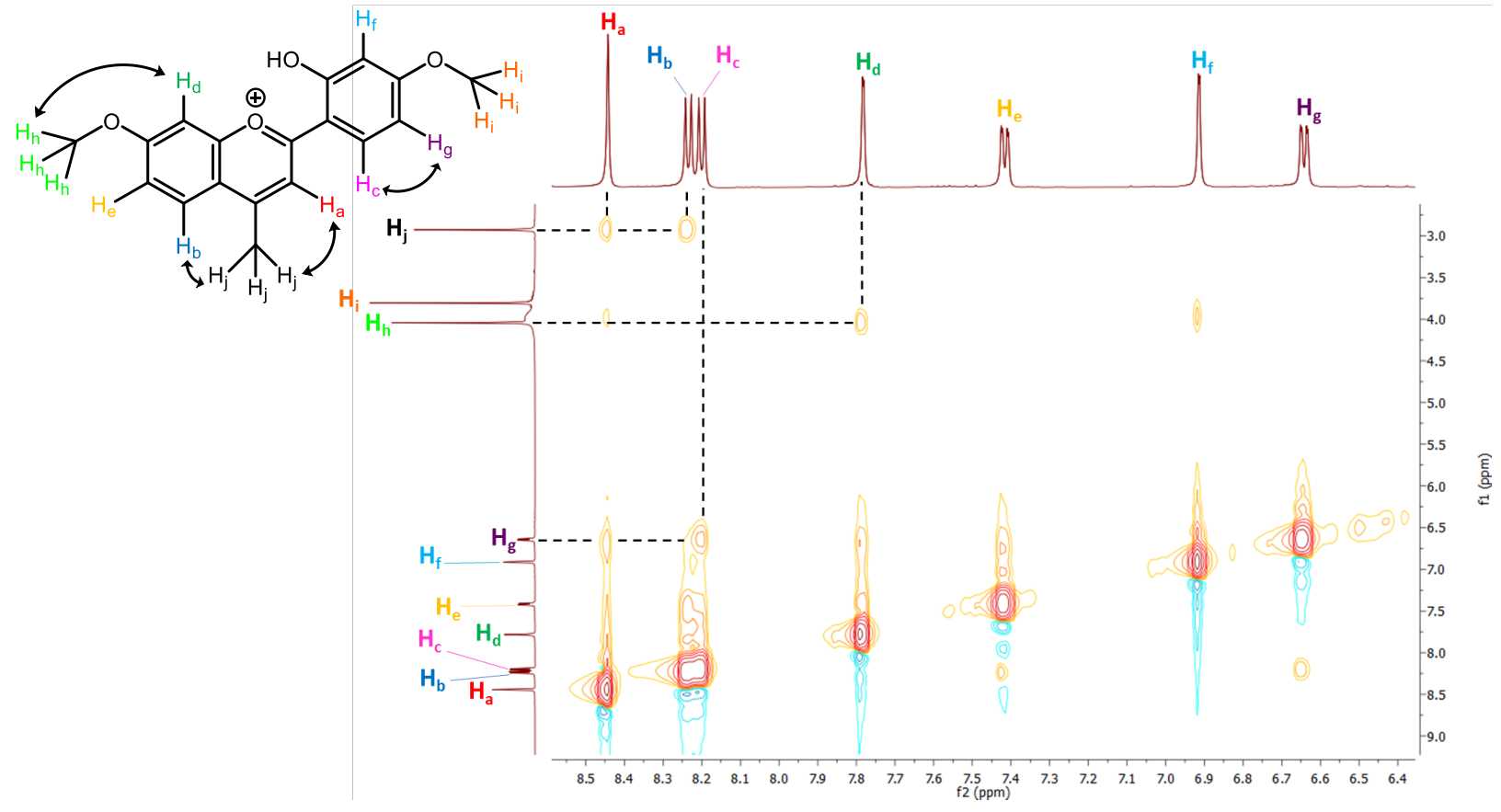

Figure S29. ${ }^{1} \mathrm{H}-{ }^{1} \mathrm{H}$ NOESY NMR $(600 \mathrm{MHz}, 298 \mathrm{~K})$ spectrum of anthocyanidin 31 in $d_{6}$-DMSO. 

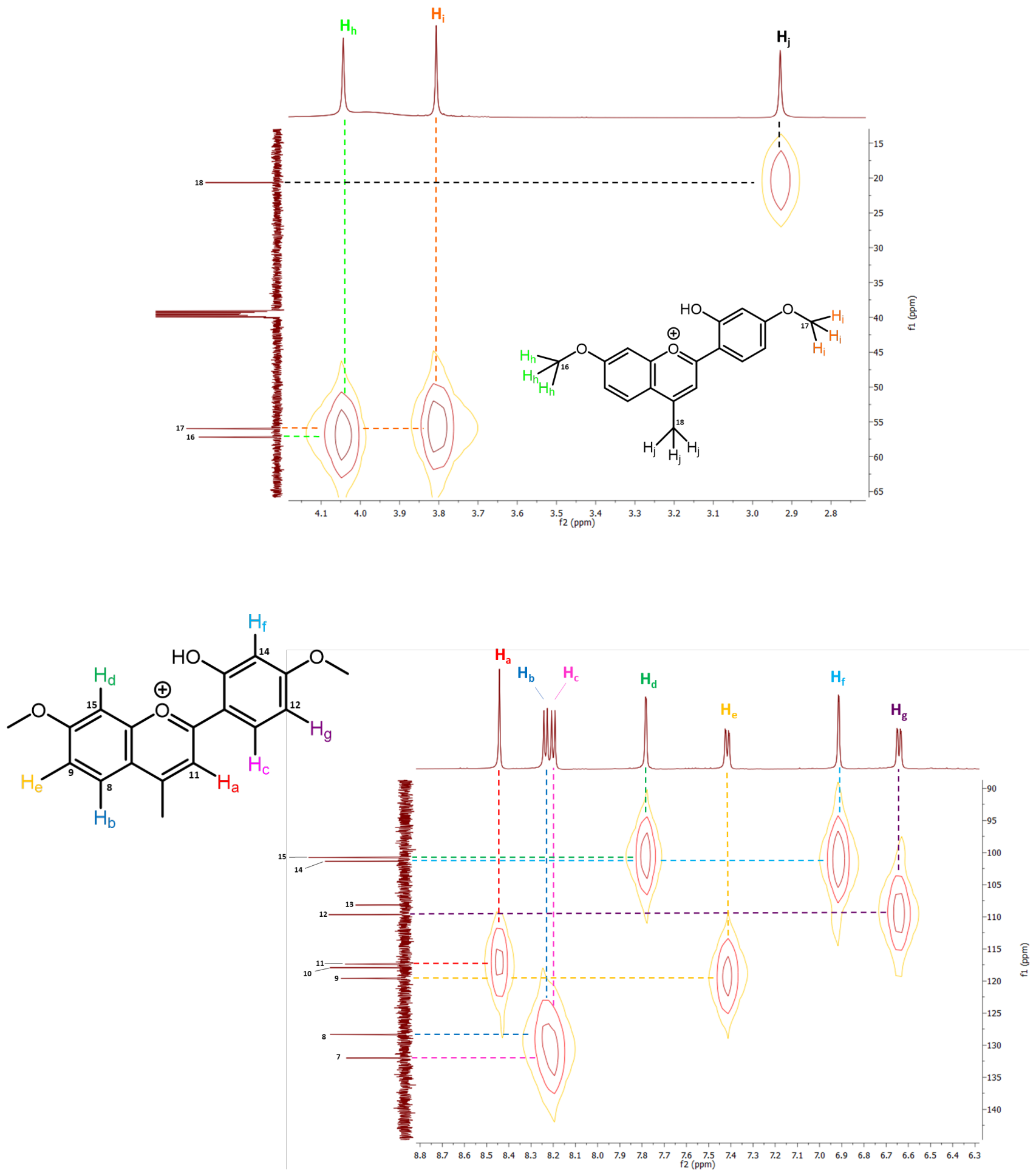

Figure S30. Two different regions of ${ }^{1} \mathrm{H}_{-}{ }^{13} \mathrm{C}$ HSQC NMR (600 MHz, $298 \mathrm{~K}$ ) spectrum of anthocyanidin 31 in $d_{6}$-DMSO. 

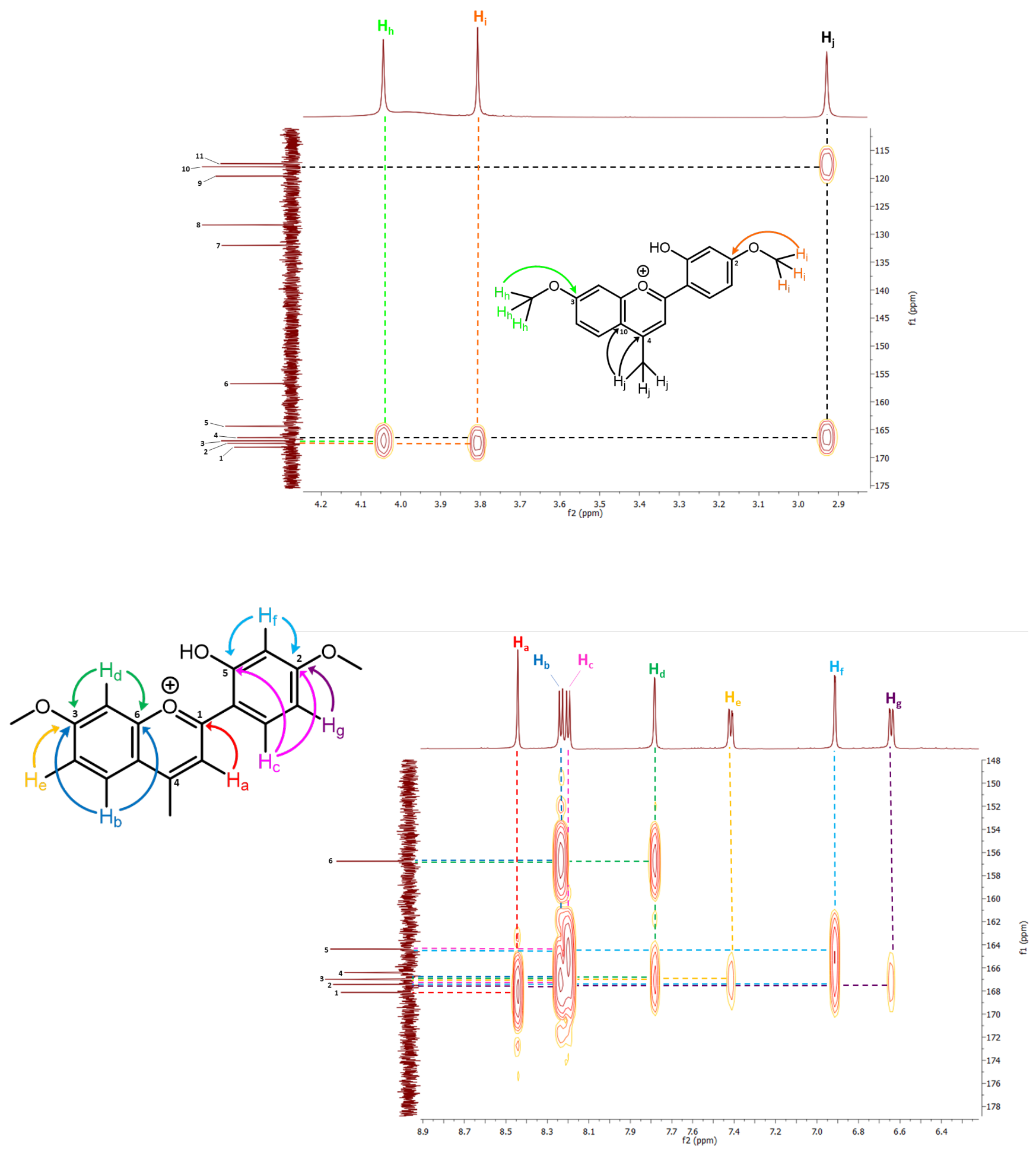

Figure S31. Two different regions of ${ }^{1} \mathrm{H}-{ }^{13} \mathrm{C}$ HMBC NMR (600 MHz, $298 \mathrm{~K}$ ) spectrum of anthocyanidin 31 in $d_{6}$-DMSO. 


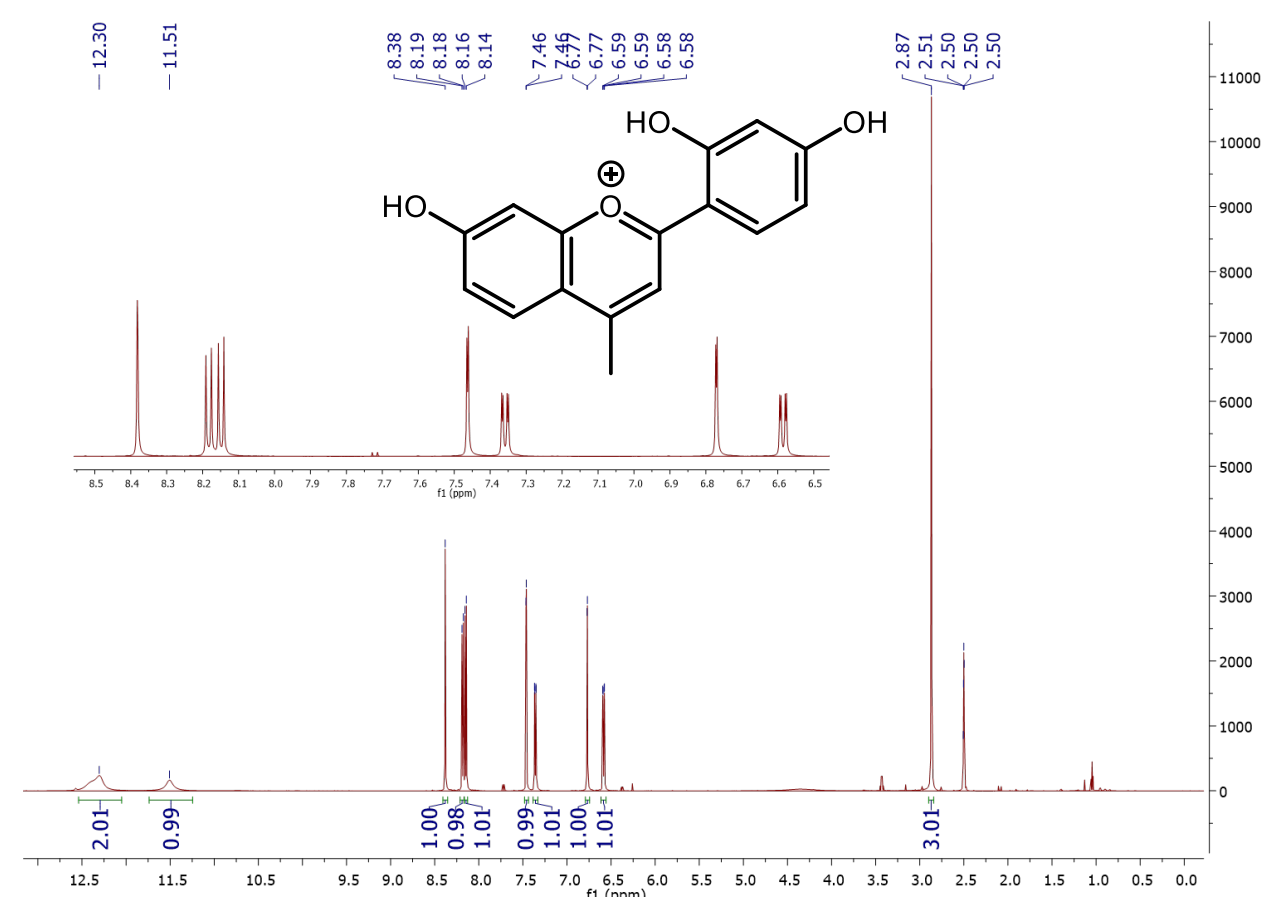

Figure S32. ${ }^{1} \mathrm{H}$ NMR spectrum $(600 \mathrm{MHz}, 298 \mathrm{~K})$ of anthocyanidin 32 in $d_{6}$-DMSO.

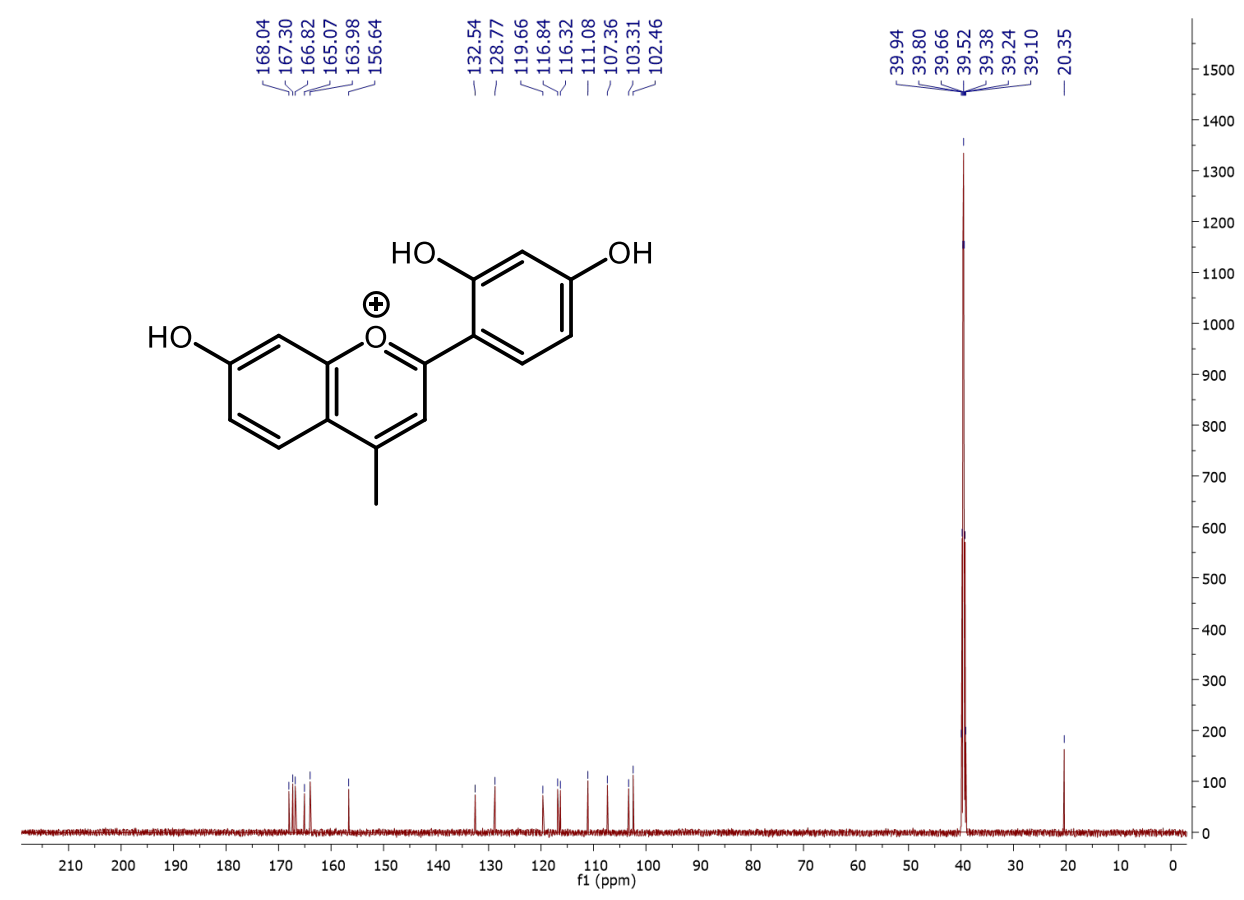

Figure S33. ${ }^{13} \mathrm{C}$ NMR spectrum $(150 \mathrm{MHz}, 298 \mathrm{~K})$ of anthocyanidin 32 in $d_{6}$-DMSO. 


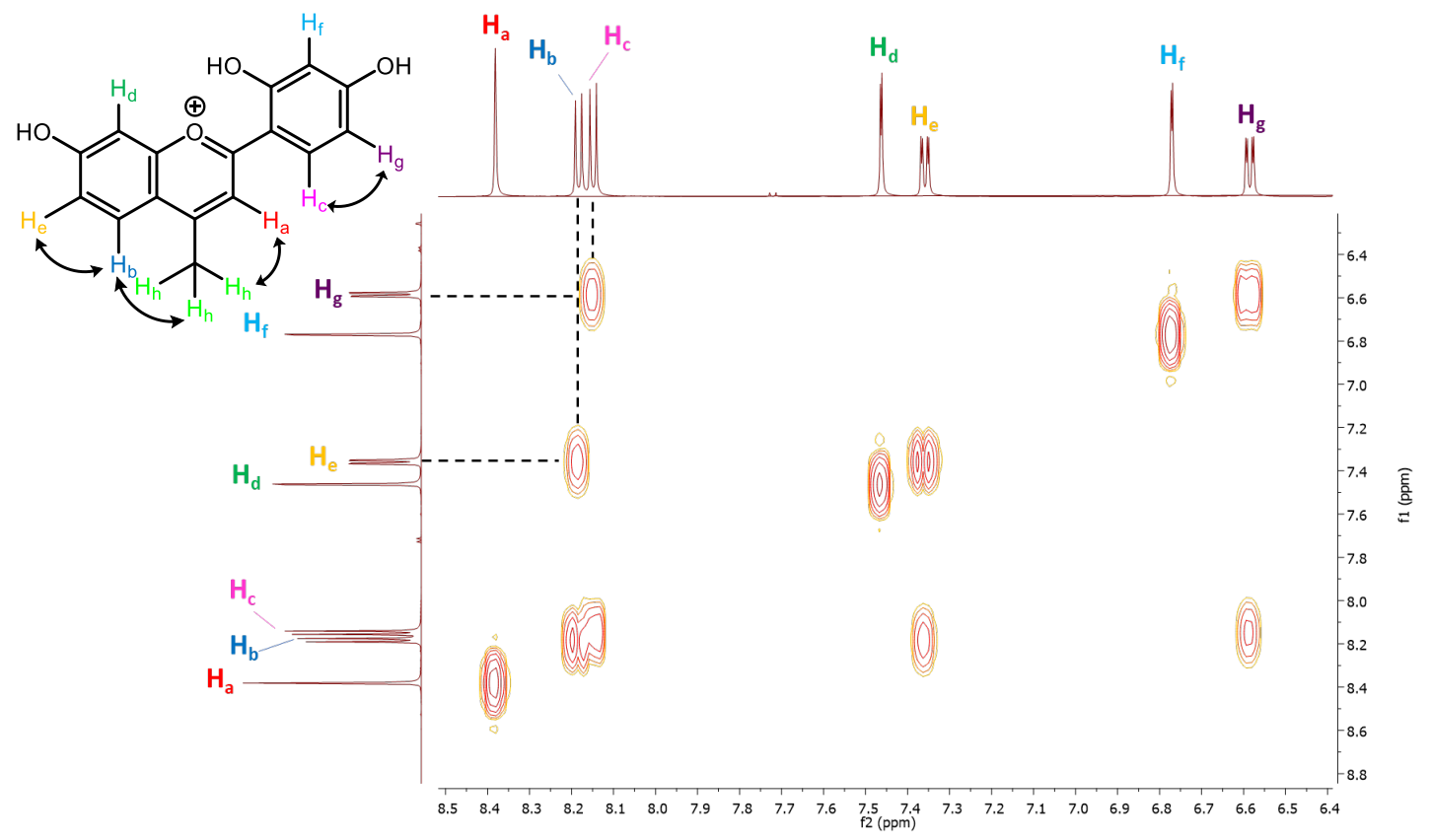

Figure S34. ${ }^{1} \mathrm{H}-{ }^{1} \mathrm{H}$ COSY NMR $(600 \mathrm{MHz}, 298 \mathrm{~K})$ spectrum of anthocyanidin 32 in $d_{6}$-DMSO.

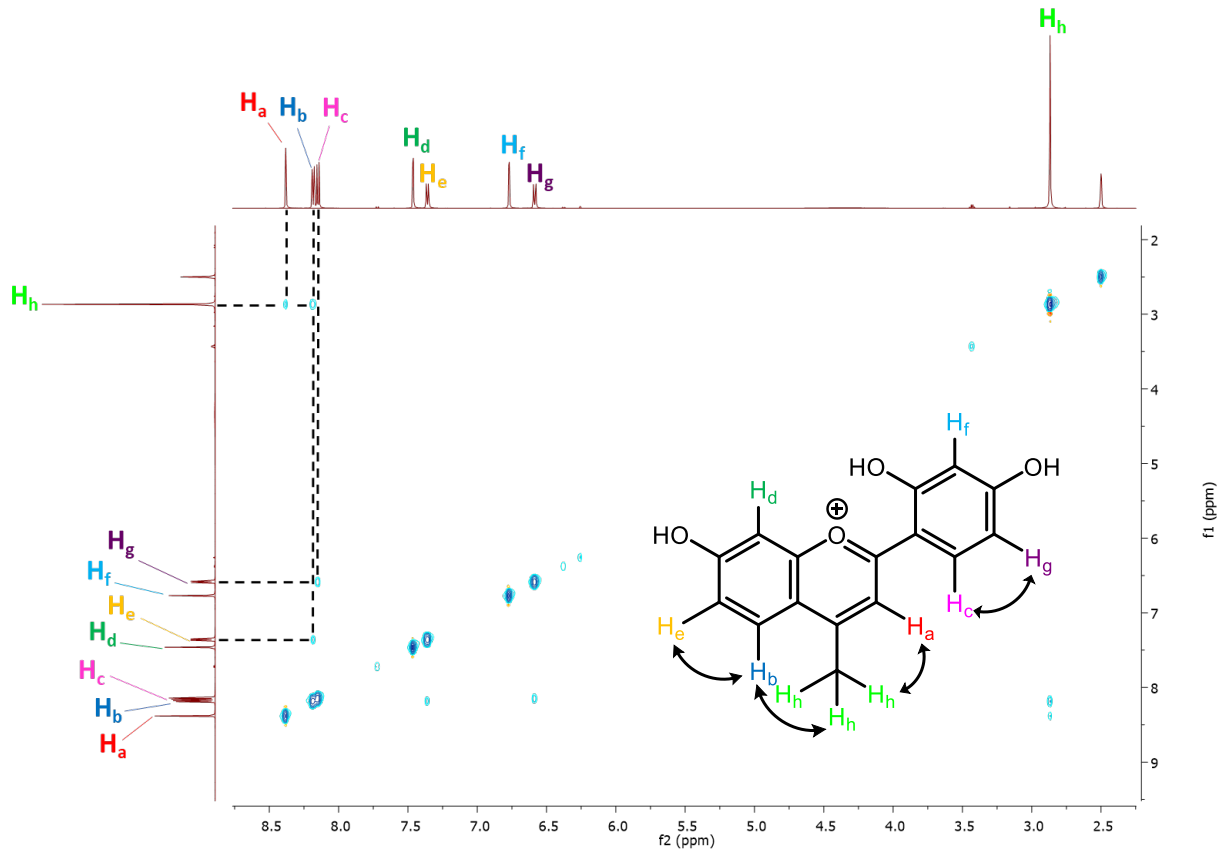

Figure S35. ${ }^{1} \mathrm{H}-{ }^{1} \mathrm{H}$ NOESY NMR $(600 \mathrm{MHz}, 298 \mathrm{~K})$ spectrum of anthocyanidin 32 in $d_{6}$-DMSO. 


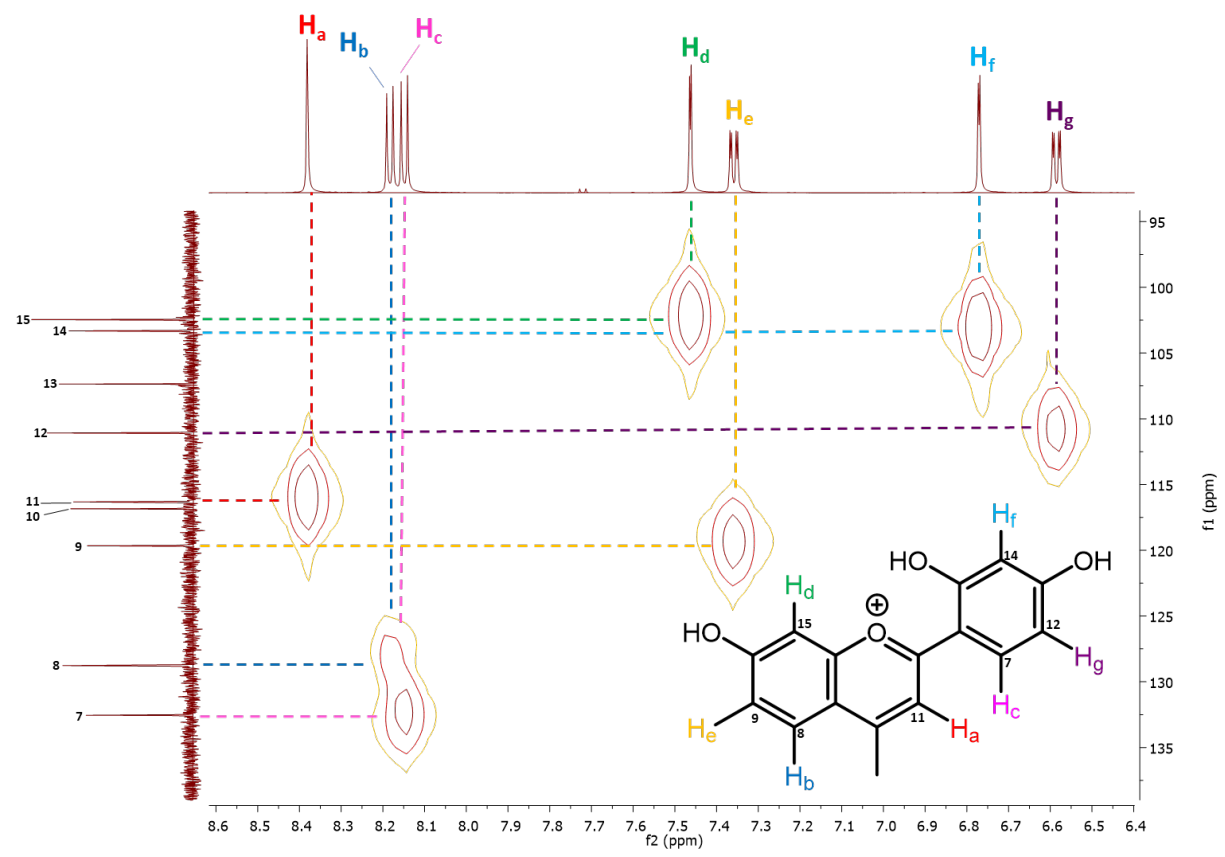

Figure S36. ${ }^{1} \mathrm{H}-{ }^{13} \mathrm{C}$ HSQC NMR $(600 \mathrm{MHz}, 298 \mathrm{~K})$ spectrum of anthocyanidin 32 in $d_{6}$-DMSO.

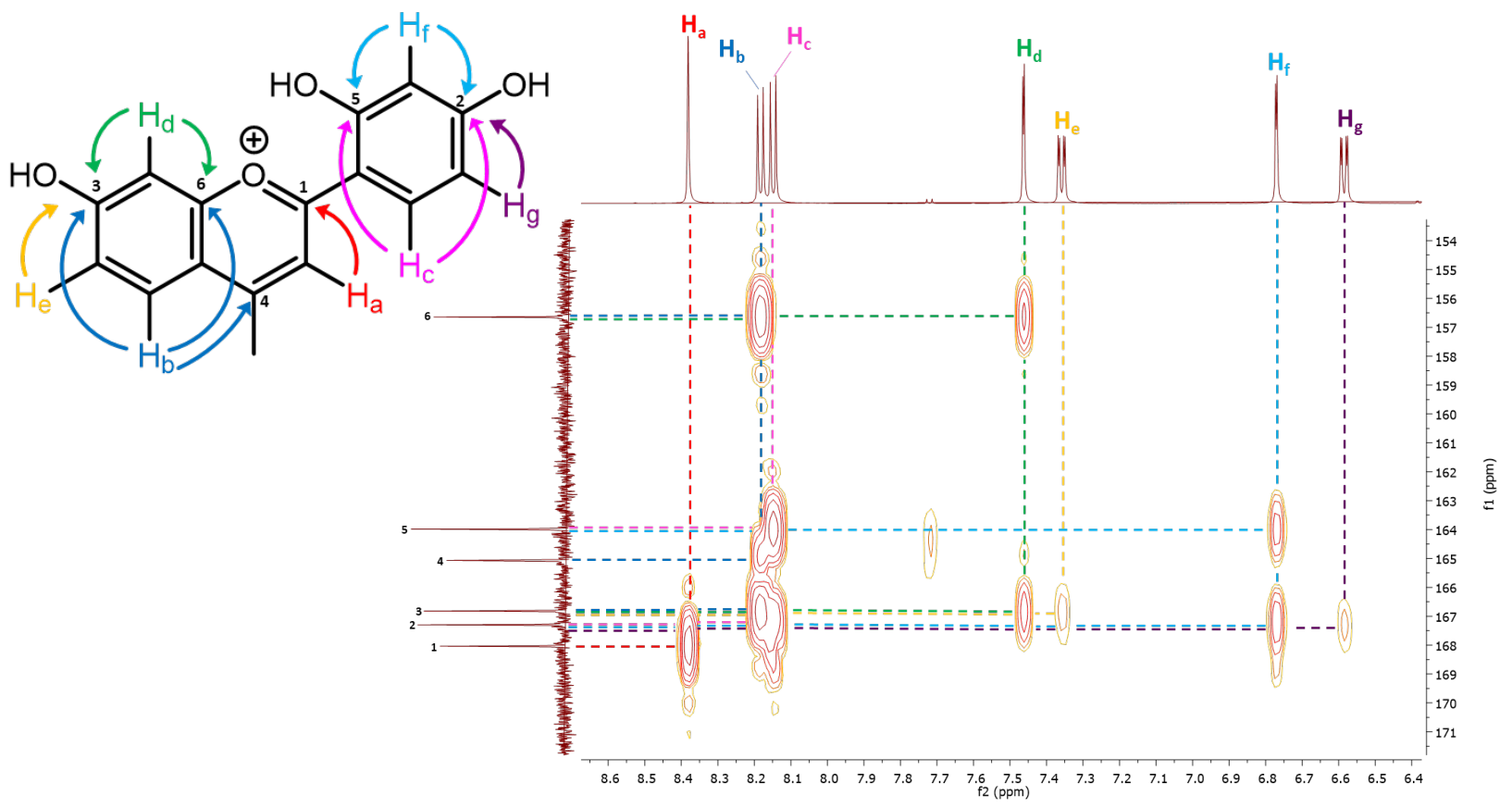

Figure S37. ${ }^{1} \mathrm{H}-{ }^{13} \mathrm{C}$ HMBC NMR (600 MHz, $\left.298 \mathrm{~K}\right)$ spectrum of anthocyanidin 32 in $d_{6}$-DMSO. 


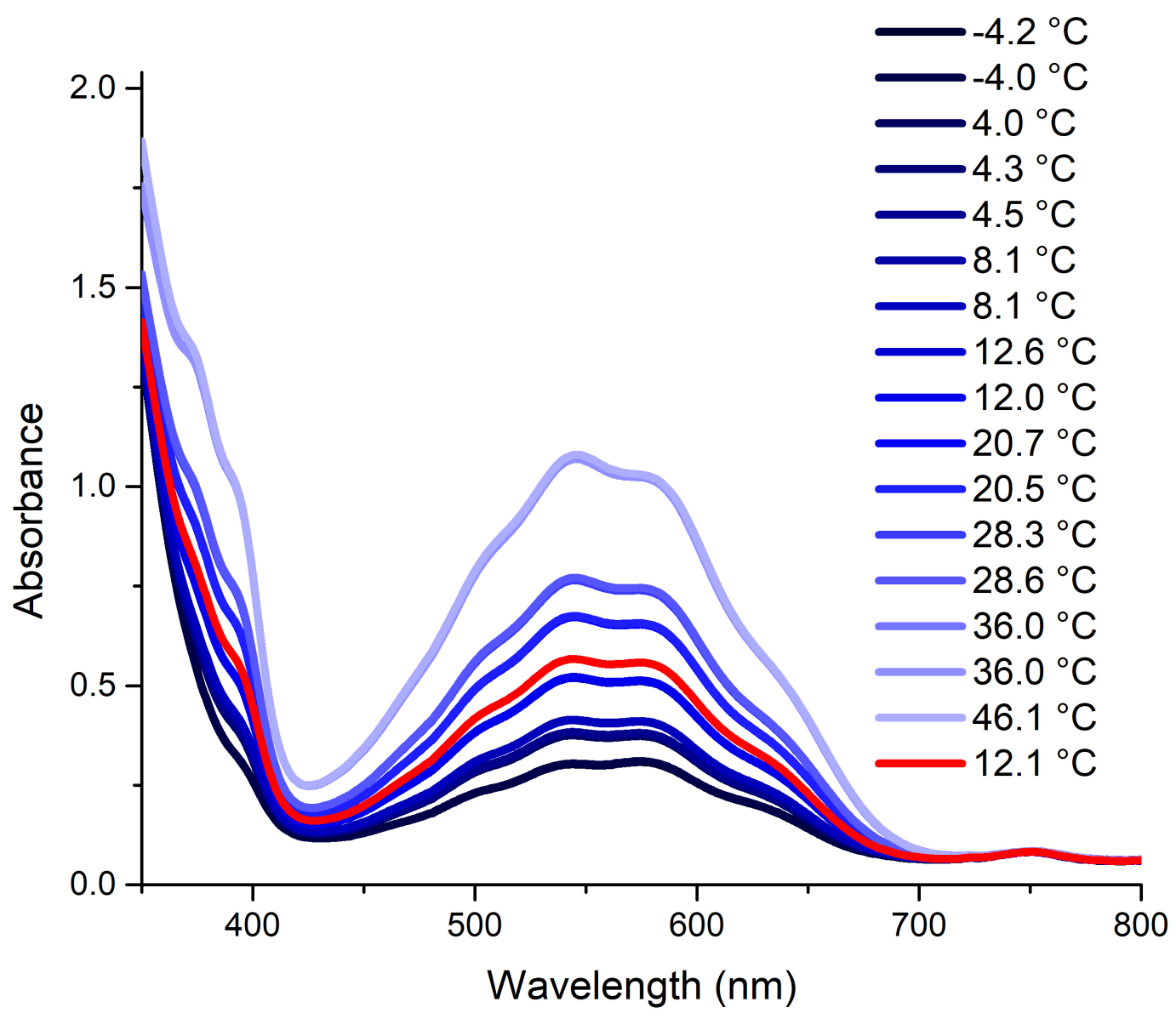

Figure S38. UV-vis spectra of $0.12 \mathrm{mM}$ solution of bis-spiropyran 30 in $\mathrm{CH}_{2} \mathrm{Cl}_{2}$ from -4.2 to $46.1{ }^{\circ} \mathrm{C}$. After reaching $46.1^{\circ} \mathrm{C}$, we reduced to temperature to $12.1^{\circ} \mathrm{C}$ with the spectrum showing that the process was not fully reversible. 


\section{Crystallographic Data}

Compound 16: The single crystal X-ray diffraction studies were carried out on a Bruker Kappa Photon II CPAD diffractometer equipped with $\mathrm{Cu} \mathrm{K}{ }_{\alpha}$ radiation $(\lambda=1.54178)$. A $0.197 \times 0.153 \times 0.118 \mathrm{~mm}$ piece of a colorless block was mounted on a Cryoloop with Paratone oil. Data were collected in a nitrogen gas stream at $100(2) \mathrm{K}$ using $\phi$ and $\varpi$ scans. Crystal-to-detector distance was $60 \mathrm{~mm}$ using variable exposure time ( $2 \mathrm{~s}-10 \mathrm{~s})$ depending on $\theta$ with a scan width of $1.0^{\circ}$. Data collection was $99.6 \%$ complete to $68.00^{\circ}$ in A. A total of 20163 reflections were collected covering the indices, $-13<=\mathrm{h}<=13,-9<=\mathrm{k}<=12,-28<=\mathrm{k}<=27$. 4420 reflections were found to be symmetry independent, with a $R_{\text {int }}$ of 0.0269 . Indexing and unit cell refinement indicated a primitive, monoclinic lattice. The space group was found to be $P 2_{1} / c$. The data were integrated using the Bruker SAINT software program and scaled using the SADABS software program. Solution by direct methods (SHELXT) produced a complete phasing model for refinement.

All nonhydrogen atoms were refined anisotropically by full-matrix least-squares (SHELXL-2014). All hydrogen atoms were placed using a riding model. Their positions were constrained relative to their parent atom using the appropriate HFIX command in SHELXL-2014. Crystallographic data are summarized in Table S1. 


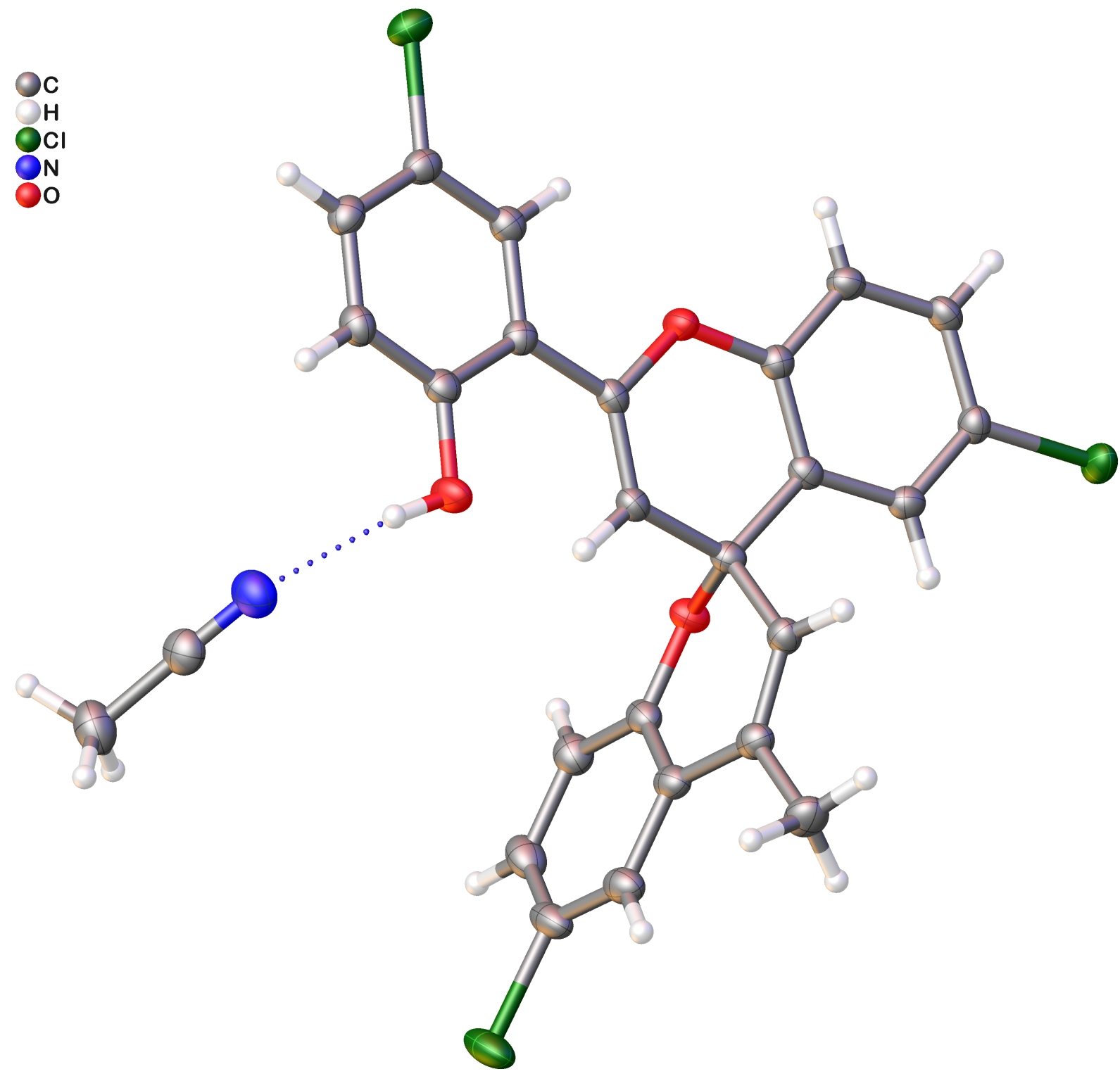

ORTEP plot of compound $\mathbf{1 6}$ (50\% probability), grown by a slow evaporation of its acetonitrile solution. 
Table S1. Crystal data and structure refinement for compound $\mathbf{1 6 .}$

\begin{tabular}{|c|c|c|}
\hline Report date & \multicolumn{2}{|l|}{$2020-03-18$} \\
\hline Identification code & \multicolumn{2}{|l|}{ TN_ChloroClosed } \\
\hline Empirical formula & \multicolumn{2}{|l|}{ C26 H18 C13 N O3 } \\
\hline Molecular formula & \multicolumn{2}{|c|}{$\mathrm{C} 24 \mathrm{H} 15 \mathrm{Cl} 3 \mathrm{O} 3, \mathrm{C} 2 \mathrm{H} 3 \mathrm{~N}$} \\
\hline Formula weight & \multicolumn{2}{|l|}{498.76} \\
\hline Temperature & \multicolumn{2}{|l|}{$100 \mathrm{~K}$} \\
\hline Wavelength & \multicolumn{2}{|l|}{$1.54178 \AA$} \\
\hline Crystal system & \multicolumn{2}{|l|}{ Monoclinic } \\
\hline Space group & \multicolumn{2}{|l|}{ P $121 / \mathrm{c} 1$} \\
\hline \multirow[t]{3}{*}{ Unit cell dimensions } & $a=10.7830(2) \AA$ & $\alpha=90^{\circ}$ \\
\hline & $\mathrm{b}=9.0950(2) \AA$ & $\beta=96.6440(10)^{\circ}$. \\
\hline & $c=22.4992(4) \AA$ & $\gamma=90^{\circ}$ \\
\hline Volume & \multicolumn{2}{|l|}{$2191.71(7) \AA^{3}$} \\
\hline $\mathrm{Z}$ & \multicolumn{2}{|l|}{4} \\
\hline Density (calculated) & \multicolumn{2}{|l|}{$1.512 \mathrm{Mg} / \mathrm{m}^{3}$} \\
\hline Absorption coefficient & \multicolumn{2}{|l|}{$4.043 \mathrm{~mm}^{-1}$} \\
\hline $\mathrm{F}(000)$ & \multicolumn{2}{|l|}{1024} \\
\hline Crystal size & \multicolumn{2}{|c|}{$0.197 \times 0.153 \times 0.118 \mathrm{~mm}^{3}$} \\
\hline Crystal color, habit & \multicolumn{2}{|l|}{ Colorless Block } \\
\hline Theta range for data collection & \multicolumn{2}{|l|}{3.956 to $74.555^{\circ}$. } \\
\hline Index ranges & \multicolumn{2}{|c|}{$-13<=\mathrm{h}<=13,-9<=\mathrm{k}<=11,-28<=\mathrm{l}<=27$} \\
\hline Reflections collected & \multicolumn{2}{|l|}{20163} \\
\hline
\end{tabular}


Independent reflections

Completeness to theta $=68.000^{\circ}$

Absorption correction

Max. and min. transmission

Refinement method

Data / restraints / parameters

Goodness-of-fit on $\mathrm{F}^{2}$

Final $\mathrm{R}$ indices [I $>2 \operatorname{sigma}(\mathrm{I})]$

$\mathrm{R}$ indices (all data)

Extinction coefficient

Largest diff. peak and hole
$4420[\mathrm{R}(\mathrm{int})=0.0269, \mathrm{R}(\mathrm{sigma})=0.0196]$

$99.6 \%$

Semi-empirical from equivalents

0.3260 and 0.1942

Full-matrix least-squares on $\mathrm{F}^{2}$

4420 / 0 / 301

1.053

$\mathrm{R} 1=0.0359, \mathrm{wR} 2=0.0923$

$\mathrm{R} 1=0.0386, \mathrm{wR} 2=0.0946$

$\mathrm{n} / \mathrm{a}$

1.052 and -0.547 e. $\AA^{-3}$ 
Compound 17: The single crystal X-ray diffraction studies were carried out on a Bruker Kappa Photon II CPAD diffractometer equipped with Mo $K_{\alpha}$ radiation $(\lambda=0.71073 \AA$ ). $A 0.326 \times 0.257 \times 0.224 \mathrm{~mm}$ piece of a redish orange block was mounted on MiTeGen Micromount with CHRISTO-LUBE MCG 1024 oil. Data were collected in a nitrogen gas stream at $100(2) \mathrm{K}$ using $\phi$ and $\varpi$ scans. Crystal-to-detector distance was $60 \mathrm{~mm}$ using variable exposure time (2s-10s) depending on $\theta$ with a scan width of $1.0^{\circ}$. Data collection was $99.6 \%$ complete to $25.00^{\circ}$ in $\theta$. A total of 25940 reflections were collected covering the indices, $-14<=\mathrm{h}<=10,-12<=\mathrm{k}<=12,-30<=\mathrm{k}<=30.5440$ reflections were found to be symmetry independent, with a $R_{\text {int }}$ of 0.0324 . Indexing and unit cell refinement indicated a primitive, monoclinic lattice. The space group was found to be $P 2_{1} / c$. The data were integrated using the Bruker SAINT software program and scaled using the SADABS software program. Solution by direct methods (SHELXT) produced a complete phasing model consistent with the proposed structure.

All nonhydrogen atoms were refined anisotropically by full-matrix least-squares (SHELXL-2014). All hydrogen atoms were placed using a riding model. Their positions were constrained relative to their parent atom using the appropriate HFIX command in SHELXL-2014. Crystallographic data are summarized in Table S2. 


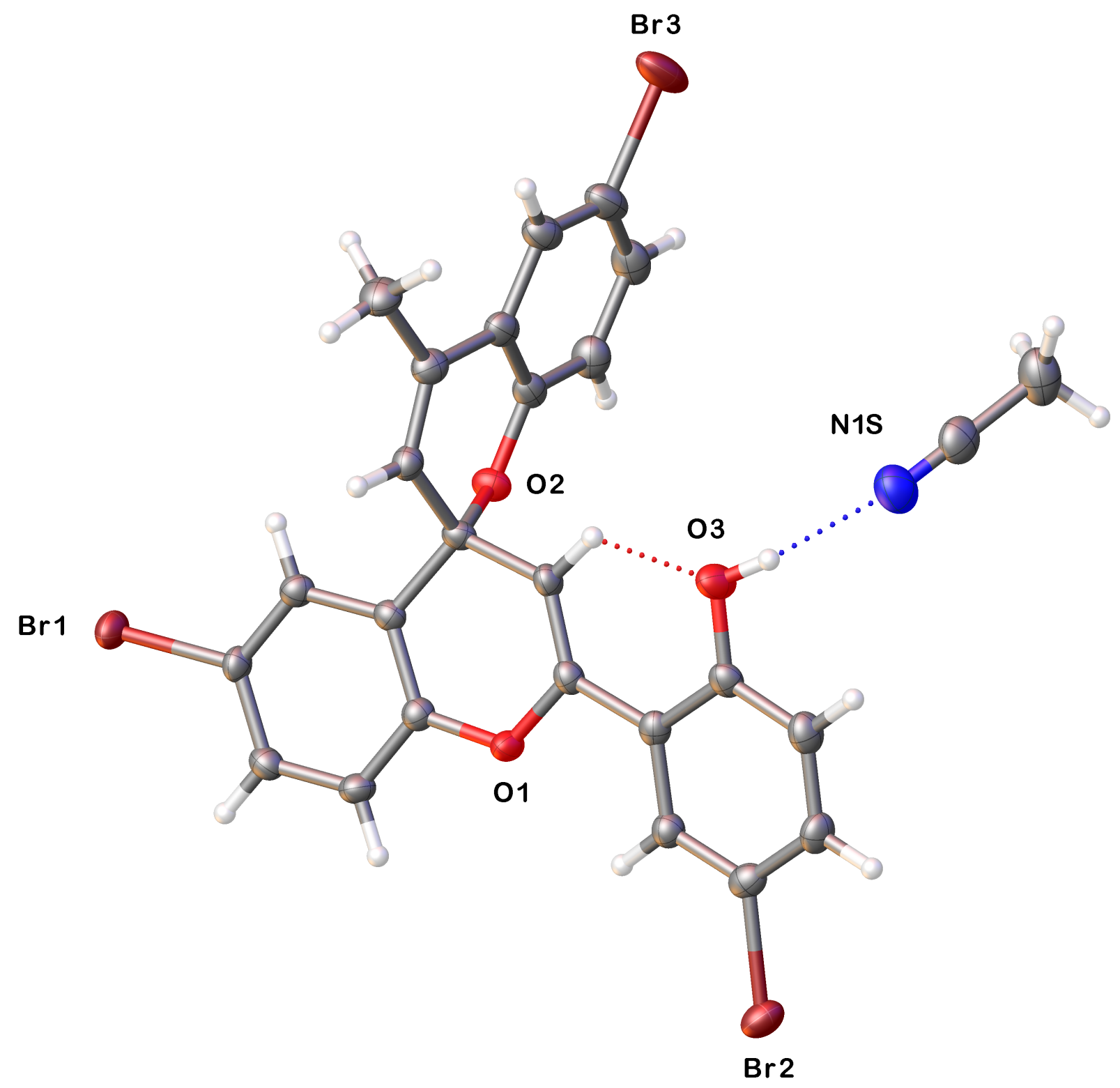

ORTEP plot of compound 17 (50\% probability), grown by a slow evaporation of its acetonitrile solution. 
Table S2. Crystal data and structure refinement for compound 17.

Report date

Identification code

Empirical formula

Molecular formula

Formula weight

Temperature

Wavelength

Crystal system

Space group

Unit cell dimensions

Volume

Z

Density (calculated)

Absorption coefficient

$\mathrm{F}(000)$

Crystal size

Crystal color, habit

Theta range for data collection

Index ranges

Reflections collected

Independent reflections
2019-05-13

TN_ClosedCH3CN

C26 H18 Br3 N O3

C24 H15 Br3 O3, C2 H3 N

632.14

$100.0 \mathrm{~K}$

$0.71073 \AA$

Monoclinic

P $121 / \mathrm{c} 1$

$\mathrm{a}=11.0228(6) \AA$

$\alpha=90^{\circ}$.

$b=9.1224(6) \AA$

$\beta=95.723(2)^{\circ}$.

$c=22.8268(14) \AA$

$\gamma=90^{\circ}$.
$2283.9(2) \AA^{3}$

4

$1.838 \mathrm{Mg} / \mathrm{m}^{3}$

$5.329 \mathrm{~mm}^{-1}$

1240

$0.326 \times 0.257 \times 0.224 \mathrm{~mm}^{3}$

Redish Orange Block

2.864 to $28.293^{\circ}$.

$-14<=\mathrm{h}<=10,-12<=\mathrm{k}<=12,-30<=\mathrm{l}<=30$

25940

$5440[\mathrm{R}($ int $)=0.0324, \mathrm{R}(\operatorname{sigma})=0.0303]$ 
Completeness to theta $=25.000^{\circ}$

Absorption correction

Max. and min. transmission

Refinement method

Data / restraints / parameters

Goodness-of-fit on $\mathrm{F}^{2}$

Final $\mathrm{R}$ indices $[\mathrm{I}>2 \operatorname{sigma}(\mathrm{I})]$

$\mathrm{R}$ indices (all data)

Extinction coefficient

Largest diff. peak and hole 1.931 and -1.298 e. $\AA^{-3}$
$99.6 \%$

Semi-empirical from equivalents

0.0962 and 0.0466

Full-matrix least-squares on $\mathrm{F}^{2}$

$5440 / 0 / 301$

1.070

$\mathrm{R} 1=0.0394, \mathrm{wR}_{2}=0.0856$

$\mathrm{R} 1=0.0548, \mathrm{wR} 2=0.0907$

$\mathrm{n} / \mathrm{a}$ 
Compound 32 (methanol): The single crystal X-ray diffraction studies were carried out on a Nonius Kappa diffractometer equipped with a Bruker APEX-II CCD and Mo $K_{\alpha}$ radiation $(\lambda=0.71073 \AA$ A). A $0.135 \times 0.126$ x $0.084 \mathrm{~mm}$ piece of a colorless block was mounted on a MiTeGen Micromount with CHRISTO-LUBE MCG 1024 oil. Data were collected in a nitrogen gas stream at 100(2) K using $\phi$ and $\varpi$ scans. Crystal-to-detector distance was $50 \mathrm{~mm}$ and exposure time was 10 seconds per frame using a scan width of $1.0^{\circ}$. Data collection was $100 \%$ complete to $25.00^{\circ}$ in $\theta$. A total of 22284 reflections were collected covering the indices, $-11<=h<=11,-17<=\mathrm{k}<=17,-15<=\mid<=15.3129$ reflections were found to be symmetry independent, with a $R_{\text {int }}$ of 0.0427 . Indexing and unit cell refinement indicated a primitive, monoclinic lattice. The space group was found to be $P 2_{1} / \mathrm{n}$. The data were integrated using the Bruker SAINT software program and scaled using the SADABS software program. Solution by direct methods (SHELXT) produced a complete phasing model consistent with the proposed structure. All nonhydrogen atoms were refined anisotropically by full-matrix least-squares (SHELXL-2014). All hydrogen atoms were placed using a riding model. Their positions were constrained relative to their parent atom using the appropriate HFIX command in SHELXL-2014. Crystallographic data are summarized in Table S3. 


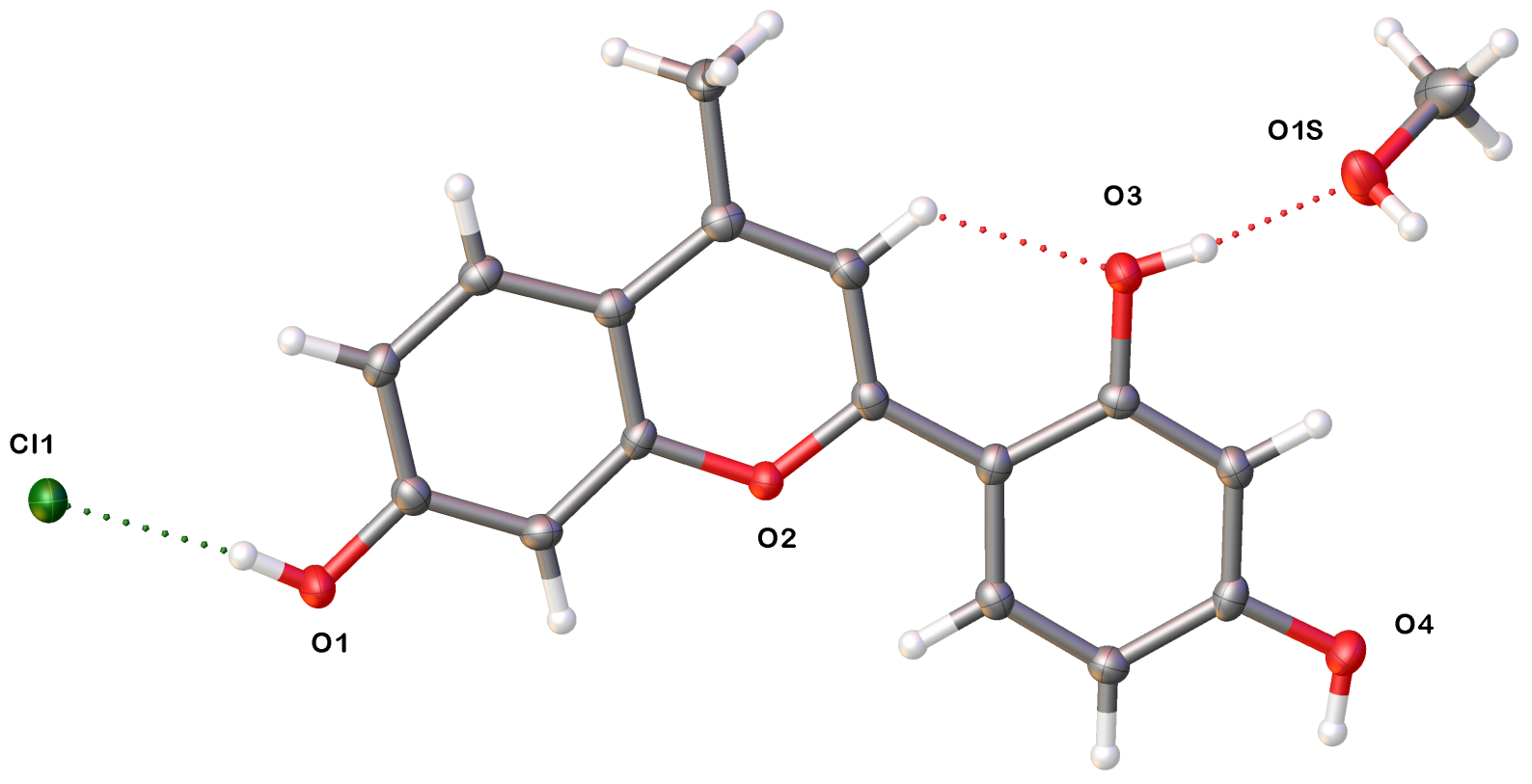

ORTEP plot of compound 32 (50\% probability). Compound $\mathbf{3 2}$ was dissolved in methanol and then acetonitrile was carefully layered on top. The vial was loosely capped to allow slow evaporation of the solvents. Two polymorphs appeared from this mixture after several days. 
Table S3. Crystal data and structure refinement for compound 32 (methanol).

Report date

Identification code

Empirical formula

Molecular formula

Formula weight

Temperature

Wavelength

Crystal system

Space group

Unit cell dimensions

Volume

Z

Density (calculated)

Absorption coefficient

$\mathrm{F}(000)$

Crystal size

Crystal color, habit

Theta range for data collection

Index ranges
2019-05-13

TN_0301MeOH

C17 H17 Cl O5

C16 H13 O4, C H4 O, Cl

336.75

$100 \mathrm{~K}$

$0.71073 \AA$

Monoclinic

P $121 /$ n 1

$a=9.1565(3) \AA$

$\alpha=90^{\circ}$.

$\mathrm{b}=14.1329(5) \AA$

$\beta=106.165(2)^{\circ}$.

$\mathrm{c}=12.2218(4) \AA$

$\gamma=90^{\circ}$.

1519.07(9) $\AA^{3}$

4

$1.472 \mathrm{Mg} / \mathrm{m}^{3}$

$0.276 \mathrm{~mm}^{-1}$

704

$0.135 \times 0.126 \times 0.084 \mathrm{~mm}^{3}$

Colorless Block

2.255 to $26.428^{\circ}$.

$-11<=\mathrm{h}<=11,-17<=\mathrm{k}<=17,-15<=\mathrm{l}<=15$ 
Reflections collected

Independent reflections

Completeness to theta $=25.000^{\circ}$

Absorption correction

Max. and min. transmission

Refinement method

Data / restraints / parameters

Goodness-of-fit on $\mathrm{F}^{2}$

Final $\mathrm{R}$ indices [I $>2 \operatorname{sigma}(\mathrm{I})]$

$\mathrm{R}$ indices (all data)

Extinction coefficient

Largest diff. peak and hole
22284

$3129[\mathrm{R}(\mathrm{int})=0.0427, \mathrm{R}($ sigma $)=0.0300]$

$100.0 \%$

Semi-empirical from equivalents

0.2602 and 0.2326

Full-matrix least-squares on $\mathrm{F}^{2}$

$3129 / 0 / 214$

1.046

$\mathrm{R} 1=0.0367, \mathrm{wR} 2=0.0972$

$\mathrm{R} 1=0.0511, \mathrm{wR} 2=0.1043$

$\mathrm{n} / \mathrm{a}$

0.323 and -0.299 e. $\AA^{-3}$ 
Compound 32 (neat): The single crystal X-ray diffraction studies were carried out on a Bruker Kappa Photon II CPAD diffractometer equipped with Mo $\mathrm{K}_{\alpha}$ radiation $(\lambda=0.71073 \AA$ A $) . \quad$ A $0.164 \times 0.157 \times 0.148$ $\mathrm{mm}$ piece of a colorless block was mounted on MiTeGen Micromount with CHRISTO-LUBE MCG 1024 oil. Data were collected in a nitrogen gas stream at 100(2) K using $\phi$ and $\varpi$ scans. Crystal-to-detector distance was $60 \mathrm{~mm}$ using variable exposure time (4s-10s) depending on $\theta$ with a scan width of $1.0^{\circ}$. Data collection was $99.9 \%$ complete to $25.00^{\circ}$ in $\theta$. A total of 13855 reflections were collected covering the indices, $-7<=h<=5,-19<=k<=19,-17<=\mid<=17.2718$ reflections were found to be symmetry independent, with a $\mathrm{R}_{\mathrm{int}}$ of 0.0343 . Indexing and unit cell refinement indicated a primitive, monoclinic lattice. The space group was found to be $P 2_{1} / c$. The data were integrated using the Bruker SAINT software program and scaled using the SADABS software program. Solution by direct methods (SHELXT) produced a complete phasing model consistent with the proposed structure.

All nonhydrogen atoms were refined anisotropically by full-matrix least-squares (SHELXL-2014). All hydrogen atoms were placed using a riding model. Their positions were constrained relative to their parent atom using the appropriate HFIX command in SHELXL-2014. Crystallographic data are summarized in Table S4. 


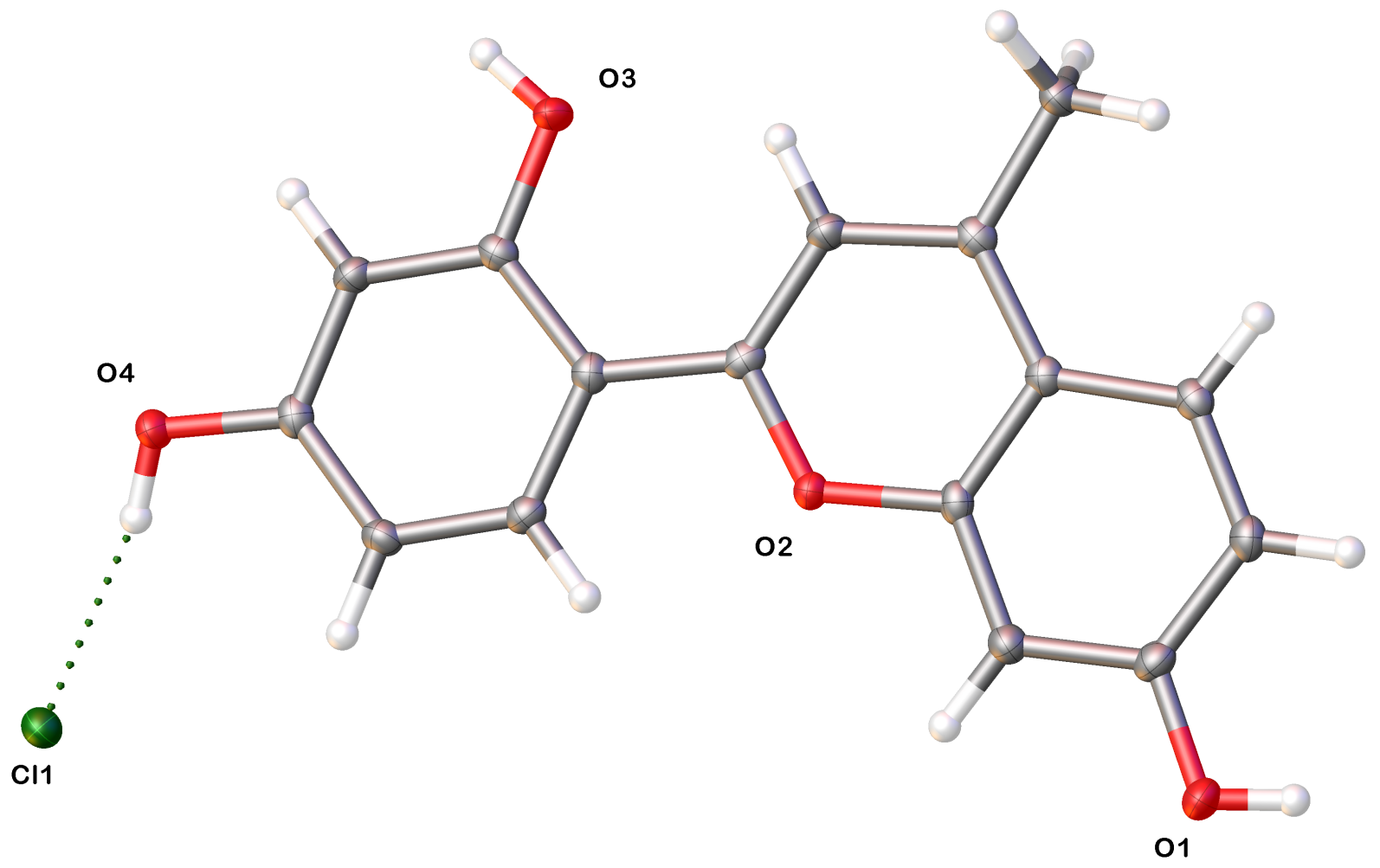

ORTEP plot of compound 32 (50\% probability). Compound 32 was dissolved in methanol and then acetonitrile was carefully layered on top. The vial was loosely capped to allow slow evaporation of the solvents. Two polymorphs appeared from this mixture after several days. 
Table S4. Crystal data and structure refinement for compound 32 (neat).

Report date

Identification code

Empirical formula

Molecular formula

Formula weight

Temperature

Wavelength

Crystal system

Space group

Unit cell dimensions

Volume

Z

Density (calculated)

Absorption coefficient

$\mathrm{F}(000)$

Crystal size

Crystal color, habit

Theta range for data collection

Index ranges

Reflections collected

Independent reflections
2019-05-13

TN_0301Neat

C16 H13 Cl O4

C16 H13 O4, Cl

304.71

$100.0 \mathrm{~K}$

$0.71073 \AA$

Monoclinic

P $121 / \mathrm{c} 1$

$\mathrm{a}=5.9006(3) \AA$

$\alpha=90^{\circ}$.

$\mathrm{b}=15.9293(9) \AA$

$\beta=101.031(2)^{\circ}$.

$\mathrm{c}=14.4042(9) \AA$

$\gamma=90^{\circ}$.

4

$1.523 \mathrm{Mg} / \mathrm{m}^{3}$

$0.301 \mathrm{~mm}^{-1}$

632

$0.164 \times 0.157 \times 0.148 \mathrm{~mm}^{3}$

Colorless Block

2.882 to $26.380^{\circ}$.

$-7<=\mathrm{h}<=5,-19<=\mathrm{k}<=19,-17<=\mathrm{l}<=17$

13855

$2718[R($ int $)=0.0343, R(\operatorname{sigma})=0.0269]$ 
Completeness to theta $=25.000^{\circ}$

Absorption correction

Max. and min. transmission

Refinement method

Data / restraints / parameters

Goodness-of-fit on $\mathrm{F}^{2}$

Final $\mathrm{R}$ indices $[\mathrm{I}>2 \operatorname{sigma}(\mathrm{I})]$

$\mathrm{R}$ indices (all data)

Extinction coefficient

Largest diff. peak and hole
$99.9 \%$

Semi-empirical from equivalents

0.2602 and 0.2237

Full-matrix least-squares on $\mathrm{F}^{2}$

$2718 / 0 / 194$

1.044

$\mathrm{R} 1=0.0323, \mathrm{wR} 2=0.0724$

$\mathrm{R} 1=0.0450, \mathrm{wR} 2=0.0809$

$\mathrm{n} / \mathrm{a}$

0.266 and -0.263 e. $\AA^{-3}$ 
Compound 33: The single crystal X-ray diffraction studies were carried out on a Bruker Kappa Photon II CPAD diffractometer equipped with $\mathrm{Mo}_{\alpha}$ radiation $(\lambda=0.71073 \AA$ ) $) . \quad$ A $0.154 \times 0.138 \times 0.127 \mathrm{~mm}$ piece of a colorless block was mounted on a MiTeGen Micromount with CHRISTO-LUBE MCG 1024 oil. Data were collected in a nitrogen gas stream at $100(2) \mathrm{K}$ using $\phi$ and $\varpi$ scans. Crystal-to-detector distance was $40 \mathrm{~mm}$ and exposure time was 60 seconds per frame using a scan width of $1.0^{\circ}$. Data collection was $99.7 \%$ complete to $25.00^{\circ}$ in $\theta$. A total of 17236 reflections were collected covering the indices, $-13<=\mathrm{h}<=13,-$ $15<=k<=15,-14<=\mid<=14.2954$ reflections were found to be symmetry independent, with a $R_{\text {int }}$ of 0.0743. Indexing and unit cell refinement indicated a primitive, monoclinic lattice. The space group was found to be $P 2_{1} / \mathrm{n}$. The data were integrated using the Bruker SAINT software program and scaled using the SADABS software program. Solution by direct methods (SHELXT) produced a complete phasing model for refinement.

All nonhydrogen atoms were refined anisotropically by full-matrix least-squares (SHELXL-2014). All hydrogen atoms were placed using a riding model. Their positions were constrained relative to their parent atom using the appropriate HFIX command in SHELXL-2014. Crystallographic data are summarized in Table 1. 


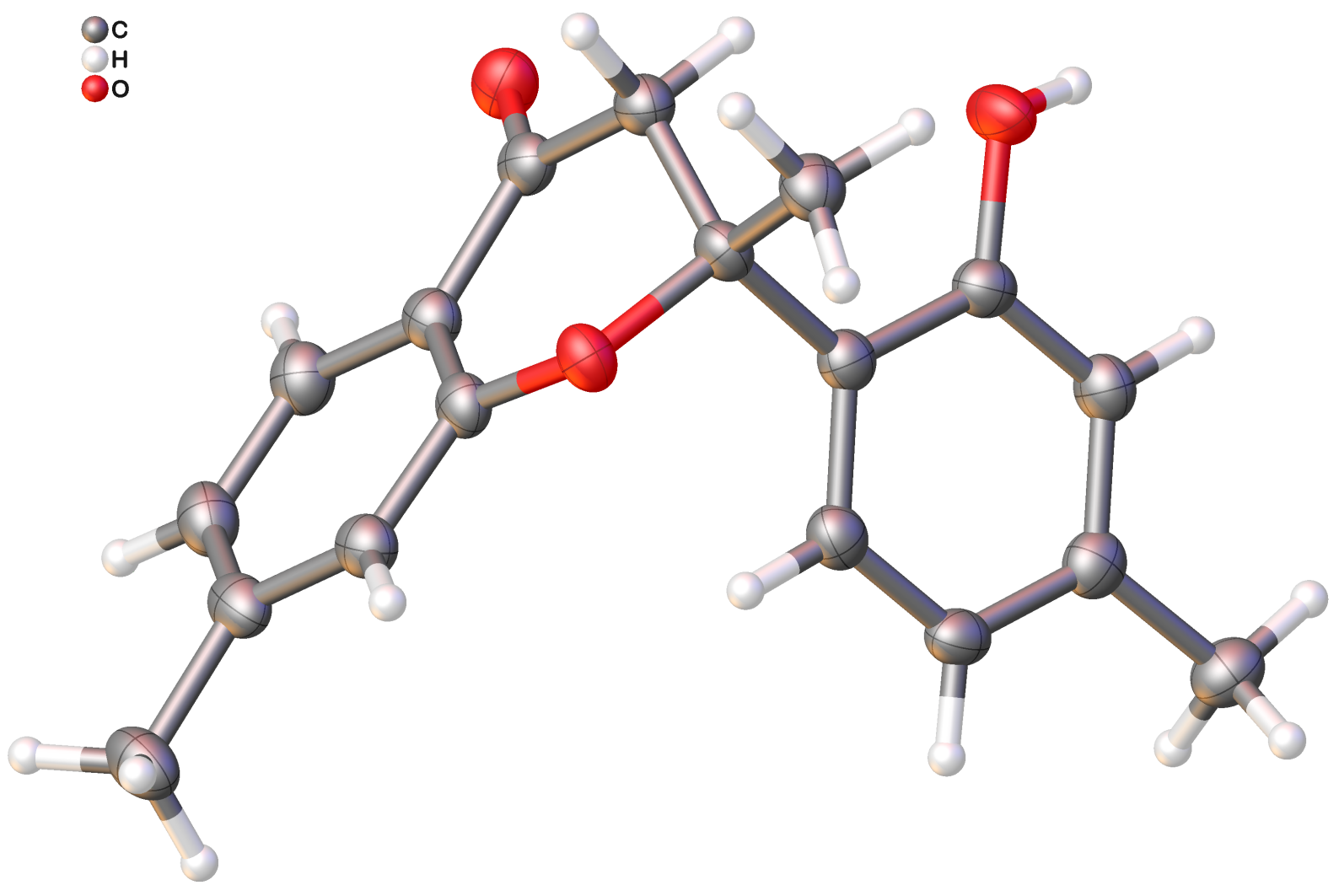

ORTEP plot of compound $\mathbf{3 3}$ (50\% probability). Compound $\mathbf{3 0}$ was dissolved in a homogenous mixture of water, acetone, acetonitrile, and methanol in a vial. A pentane layer was then carefully added on top and the vial was loosely capped to allow a slow evaporation of solvents. Roughly 1.5-2 months later, the crystals formed from a very small amount of the remaining liquid. 
Table S5. Crystal data and structure refinement for compound 33.

\begin{tabular}{|c|c|c|}
\hline Report date & \multicolumn{2}{|l|}{$2020-03-18$} \\
\hline Identification code & \multicolumn{2}{|c|}{ TN_TetramerDecomp } \\
\hline Empirical formula & \multicolumn{2}{|l|}{ C18 H18 O3 } \\
\hline Molecular formula & \multicolumn{2}{|l|}{$\mathrm{C} 18 \mathrm{H} 18 \mathrm{O} 3$} \\
\hline Formula weight & \multicolumn{2}{|l|}{282.32} \\
\hline Temperature & \multicolumn{2}{|l|}{$100 \mathrm{~K}$} \\
\hline Wavelength & \multicolumn{2}{|l|}{$0.71073 \AA$} \\
\hline Crystal system & \multicolumn{2}{|l|}{ Monoclinic } \\
\hline Space group & \multicolumn{2}{|l|}{ P $121 / \mathrm{n} 1$} \\
\hline \multirow[t]{3}{*}{ Unit cell dimensions } & $\mathrm{a}=10.5278(6) \AA$ & $\alpha=90^{\circ}$. \\
\hline & $\mathrm{b}=12.1806(6) \AA$ & $\beta=99.627(2)^{\circ}$. \\
\hline & $\mathrm{c}=11.4454(6) \AA$ & $\gamma=90^{\circ}$ \\
\hline Volume & \multicolumn{2}{|l|}{$1447.03(13) \AA^{3}$} \\
\hline $\mathrm{Z}$ & \multicolumn{2}{|l|}{4} \\
\hline Density (calculated) & \multicolumn{2}{|l|}{$1.296 \mathrm{Mg} / \mathrm{m}^{3}$} \\
\hline Absorption coefficient & \multicolumn{2}{|l|}{$0.087 \mathrm{~mm}^{-1}$} \\
\hline $\mathrm{F}(000)$ & \multicolumn{2}{|l|}{600} \\
\hline Crystal size & \multicolumn{2}{|c|}{$0.154 \times 0.138 \times 0.127 \mathrm{~mm}^{3}$} \\
\hline Crystal color, habit & \multicolumn{2}{|l|}{ Colorless Block } \\
\hline Theta range for data collection & \multicolumn{2}{|l|}{2.953 to $26.382^{\circ}$. } \\
\hline Index ranges & \multicolumn{2}{|c|}{$-13<=\mathrm{h}<=13,-15<=\mathrm{k}<=15,-14<=\mathrm{l}<=14$} \\
\hline Reflections collected & \multicolumn{2}{|l|}{17236} \\
\hline
\end{tabular}


Independent reflections

Completeness to theta $=25.000^{\circ}$

Absorption correction

Max. and min. transmission

Refinement method

Data / restraints / parameters

Goodness-of-fit on $\mathrm{F}^{2}$

Final R indices [I $>2 \operatorname{sigma}(\mathrm{I})]$

$\mathrm{R}$ indices (all data)

Extinction coefficient

Largest diff. peak and hole
$2954[\mathrm{R}(\mathrm{int})=0.0743, \mathrm{R}(\mathrm{sigma})=0.0466]$

$99.7 \%$

Semi-empirical from equivalents

0.2602 and 0.2161

Full-matrix least-squares on $\mathrm{F}^{2}$

2954 / 0 / 195

1.066

$\mathrm{R} 1=0.0457, \mathrm{wR} 2=0.1092$

$\mathrm{R} 1=0.0918, \mathrm{wR} 2=0.1402$

$0.021(4)$

0.217 and -0.235 e. $\AA^{-3}$ 